\title{
IVAN MEŠTROVIĆ I JAPANSKO DRUŠTVO KIPARA „KOZOSHA“: KIPARI KOJI SU DIJELILI ISTI SAN
}

Izraz "dijeliti isti san“ odnosi se na sintezu kiparstva i arhitekture, ali ne zato da bi se prvobitna svrha tih umjetnosti razbila, već u želji da se one spoje i kao takve prožmu sve razine društva. Taj je san početkom 20. stoljeća bio zajednički i Srednjoj Europi i Japanu. U pozadini povezanosti izmedu bečkog i japanskog ekspresionizma bili su Ivan Meštrović i secesionistički pokret. Njihov je utjecaj u Japanu doveo do stvaranja Društva kipara "Kozosha". Premda su Meštrović i članovi „Kozoshe“ potjecali iz različitih sredina, zajednička im je potraga za nacionalnim izrazom i odmak od tradicionalnih tendencija. U radu se propituje njihov odnos i silnice povezanosti u okviru razmatranja ključnih dogadaja: utemeljenja Udruge arhitekata secesionista, održavanja „Memorijalne izložbe mira" te izbijanja velikog potresa u Tokiju.

Ključne riječi: Ivan Meštrović, Društvo kipara „Kozosha“, kiparstvo, arhitektura, secesionistički pokret, Japan

Ivan Meštrović (1883. - 1962.)

M eštrović, uz novčanu potporu čovjeka koji financira njegovo školovanje, odlazi sa 17 godina u Beč, gdje su ga na Akademiji podučavali Hermann Helmer i Otto Wagner. Pod utjecajem potonjeg pridružio se secesionističkom pokretu. Gorljivi rodoljub, izradio je mnogo memorijalnih spomenika pokušavajući ujediniti kiparstvo i arhitekturu; smatraju ga jugoslavenskim Michelangelom. ${ }^{1}$

\section{Društvo kipara "Kozosha“}

Riječ je o skupini kipara iz prijeratnog razdoblja. Na izložbi „Teiten“, u organizaciji Carske akademije u rujnu 1926., kipari Sogan Saito i Jitsuzo Hinago nisu bili zadovoljni prevladavajućom tradicijom izrade isključivo skulpturâ golih tijela, već su izložili novi stil rada kao pokušaj sinteze kiparstva i arhitekture. Iste godine pridružio im se Kanji Yo, u kojega se uočava kubistički utjecaj i stil Art Deco u apstraktnoj skulpturi u novom urbanom prostoru, kao i u proleterskoj umjetnosti.

Pojavljuju se radnički pokreti i skulpture s aktualnim društvenim temama. Saito je posvećen grupnim skulpturama, ovosvjetovnim oblicima, ornamentima, odnosno dekoraciji arhitekture, spomenicima, dizajnu, obrtu te komercijalnoj umjetnosti; drugim riječima, pokušao je implementirati skulpturu u svakodnevni život.

Na 3. izložbi "Kozoshe“ (1929.) izložen je eksperimentalni rad nazvan „Koautorsko djelo", monumentalno djelo na visokoj arhitektonskoj razini. Unutar tog arhitektonskog

1 Shunyu Mitamura, Japanska enciklopedija, Shogakukan. 
prostora izloženi su i neki drugi predmeti, poput gravure tamjana, što je ukazivalo na to da razvoj kiparstva vodi do arhitekture i obrta. ${ }^{2}$

Japanska secesija bila je vezana za arhitekturu, posebice za Udrugu arhitekata secesionista. U tom je kontekstu važna "Memorijalna izložba mira“, koju su organizirali mladi arhitekti. Godine 1920. na Odjelu za arhitekturu Carskog sveučilišta u Tokiju šestero diplomanata osnovalo je prvo udruženje koje je zagovaralo arhitekturu modernizma. Osobito su značajni bili članovi Sutemi Horiguchi, Mayumi Takizawa i Mamoru Yamada.

lako su Meštrović i glavni članovi „Kozoshe“ potjecali iz različitih sredina, ulagali su sličan napor za prevladavanje tradicionalnih prepreka u svojim zemljama. $U$ tom su smislu bili u istome položaju. Htio bih na kraju detaljnijim pregledom iz današnje perspektive ocijeniti Meštrovićev san, a ujedno razmotriti i naš današnji stav prema tom snu i izazovima "Kozoshe“. Ovo nije studija o povijesti kiparstva ili povijesti umjetnosti, već esej o razmjeni ideologije i kulture (bez obzira na razlike i državne granice) te o načinu na koji bi trebalo promatrati povezanost japanske umjetnosti i društva, fokusirajući se na problem izražavanja u umjetnosti i arhitekturi.

\section{Prihvaćenost Meštrovića, secesije i njemačkog ekspresionizma u Japanu}

\section{Bečka secesija i prihvaćanje Meštrovića u Japanu}

Dana 18. kolovoza 1915., nakon izbijanja Prvoga svjetskog rata, u kulturnoj rubrici najtiražnijih japanskih novina Yomiuri Shinbun objavljen je članak "Rodin i Meštrović". Na samom početku članka navodi se da je Meštrovićeva samostalna izložba u Londonu privukla brojne posjetitelje. Spominju se kritike tih djela od strane umjetnikâ akademskog stila, dok su za djela ekspresionizma iznesene riječi hvale. „U njegovim djelima, poput plamena vatre, osjećamo entuzijazam, izazvan gorućim, rijetkim bijesom narodnog (kolektivnog) sjećanja“ ${ }^{3}$ Treba obratiti pozornost na spomenuto entuzijastično kolektivno sjećanje. Napisano je mnogo studija o tome da Meštrović u to doba nije djelovao samo kao hrvatski već i kao kipar svih južnih Slavena. ${ }^{4}$ No, želio bih nešto reći i o tome kako Japanci danas gledaju na stvaranje Jugoslavije.

\section{Stvaranje Jugoslavije. Meštrović kao kipar južnih Slavena}

Događaji koji su se odvijali u slavenskim zemljama bili su od velikog interesa za Japance, koji su u tim sukobima vidjeli sličnosti s vlastitom zemljom. Pokret za ujedinjenje južnih

2 Gen Adachi, Leksikon suvremene likovne umjetnosti, Ver. 2. 0, artscape, DNP Art Communication.

3 "Rodin i Meštrović iz periferne zemlje“, Yomiuri Shinbun, 28. 8. 1915. (「寒国のロダンメシュト ロヴイチ」、『読売新聞』、1915年8月28日付)

4 Yuko Ikeda (ur.), Zapadni suvremeni grad i umjetnost 4: Beč, Tokio 2016. (池田祐子編、『西洋近代の 都市と芸術 4 ：ウィーン』、竹林舎、2016年)

U ovoj se studiji referiram na članak: Barbara Vujanović, „The Sculptor Ivan Meštrović - Cultural and Political Diploma of the $20^{\text {th }}$ century: in the context of meeting with Czech (Czechoslovak) politicians and artists", Second Euroacademia International Conference Re-Inventing Eastern Evrope, Prague, 15 - 16 November 2013. To je dobar primjer o tome kako se danas vrednuje Meštrovićeva politička aktivnost tijekom Prvoga svjetskog rata. 
Slavena započeo je nakon izbijanja Prvoga svjetskog rata i prerastao u politički pokret, ali su se njegovi vođe razilazili u gledištima. Srpski premijer Nikola Pašić htio je ujediniti sva područja na kojima su živjeli Srbi i osigurati izlaz na more; cilj mu je bio stvoriti „Veliku Srbiju“. Nasuprot tome, Hrvati su tražili izlaz iz Austro-Ugarske Monarhije. Ta skupina, okupljena oko hrvatskih intelektualaca, osnovala je Jugoslavenski odbor. Zagovarali su raspad Monarhije i ujedinjenje južnih Slavena te su nastojali razviti dobre odnose s Velikom Britanijom, Francuskom i Rusijom. Obje strane sastale su se u srpnju 1917. i objavile Krfsku deklaraciju, koja je omogućila neovisnost pod Kraljevinom Srbijom. Dok je taj sporazum bio strateška priprema za stvaranje jedinstvene države, kasnije - ljeti 1918. - započela su velika previranja, kada je postalo jasno da se Monarhija raspala. ${ }^{5}$

Ipak, u Japanu se tada Meštrovića smatralo srpskim kiparom jer je izložio svoj rad u srpskom paviljonu na "Međunarodnoj izložbi umjetnosti“ u Rimu (1911.). Stvarna Jugoslavija bila je sasvim drugačija od one o kakvoj je sanjao. Versajskim sporazumom poslije Prvoga svjetskog rata nastojalo se Sovjetski Savez okružiti antisovjetskim zemljama, a novostvorena je Jugoslavija, umjesto federacije i decentralizacije, izabrala put centralizacije vlasti u Srbiji. Ustav o centralističkoj vladavini donesen je 1921. na Vidovdan, po čemu se i naziva Vidovdanskim ustavom. Otada je sve manje Meštrovićevih skulptura imalo političke konotacije.

Meštrovićev „Vidovdanski hram“ (oko 1906. - 1913.) sastoji se od niza spomenika južnoslavenskim žrtvama turske invazije. Taj se niz često uspoređuje s djelima Franza Metznera. Potonji je bio treća osoba koja je utjecala na Meštrovića nakon bečkog secesionista Gustava Klimta i Augustea Rodina, s kojem je neko vrijeme surađivao i izlagao. Istaknuta je sličnost Meštrovićeva koncepta monumentalnog „Vidovdanskog hrama“ s Metznerovim "Robom" (1908.), no postoje, naravno, i razlike. U vidovdanskom nizu osjeća se buđenje nacionalne svijesti, a Meštrovićev izraz dopunjuje taj koncept. On ne predstavlja heroja, kao u Metznera, koji živi sâm u izolaciji, već ratnike koji suosjećaju i tuguju.

Na Meštrovićev su izraz u velikoj mjeri utjecali Auguste Rodin, Aristide Maillol i Antoine Bourdelle. No, Rodinov impresionizam nije odgovarao ideološkom konceptu vidovdanskih skulptura, stoga se Meštrović okrenuo Metznerovu monumentalizmu. Konačno, kad je Meštrović uspio svladati Metznerov repertoar, vješto prilagođavajući grčke elemente, nastao je neoslavenski stil. ${ }^{6}$

U europskom svijetu kiparstva početkom 20. stoljeća Meštrović je dokazivao svoj talent na temeljima secesije, monumentalizma i eklekticizma. Uspio je postići da se njegove skulpture razlikuju od onih drugih kipara inkorporirajući izraz nacionalnog identiteta.

\section{Meštrović u Japanu: rana faza}

U Japanu se Meštrovićev utjecaj zamjećuje nakon Prvoga svjetskog rata. Najprije se susreo sa slikarima koji su putovali Europom i koji su posjetili "Međunarodnu izložbu umjetnosti“ u Rimu te Meštrovićevu samostalnu izložbu u Londonu. Japance je osobito privukao njegov ekspresionizam i senzibilitet prema južnim Slavenima.

5 Usp. Nobuhiro Shiba, „Yugoslavia“, Enciklopedija Nipponika, internetsko izdanje (柴宜弘、ユーゴスラ ビア、ブリタニカ日本大百科全書（ニッポニカ） 参照)

6 Usp. Isao Koshimura, „Beč i Zagreb“, u: Ikeda (ur.), Zapadni suvremeni grad i umjetnost 4, 463. (越村 勲、ウィーンとザグレブ、池田祐子編、『西洋近代の都市と芸術 4 ：ウィーン』、竹林舎、2016 年所収、463ページ) 
Hakutei Ishii, japanski likovni kritičar i slikar europskog stila, visoko je ocijenio Meštrovićevo djelo na "Međunarodnoj izložbi umjetnosti“ u Rimu 1911., opisavši ga u jednom umjetničkom časopisu: „Njegova djela odišu strahovitom snagom, (...) nečim primitivnim,

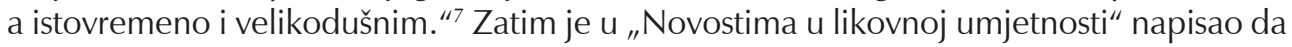
je Meštrovićeva samostalna izložba u Londonu 1915. imala velik odjek u svijetu engleske umjetnosti. ${ }^{8}$ Još je ranije bio napisao nekoliko članaka o toj temi za razne novine, među ostalima i za Yomiuri Shinbun.

Drugi slikar europskog stila, Shinpu Takamura, iskoristio je veći dio svog putopisa o Europi koji je poslao časopisu Središnja umjetnost, kako bi upoznao javnost sa životopisom i skulpturama Ivana Meštrovića. Takamura je uočio duhovne aspekte u Meštrovićevu djelu: "Sve njegove skulpture prikazuju besmrtan život srpskih žena."

\section{Meštrović u Japanu: upoznavanje s njegovim stvaralačkim radom i vrhunac. Njemački ekspresionizam i mladi japanski kipari}

Godine 1920. kipar San Takeda održao je predavanje na Carskoj umjetničkoj školi (danas Sveučilište za umjetnost u Tokiju). Tvrdio je da je Meštrović bio „najznačajniji umjetnik nakon Rodina (...) u doba (...) kada je sve bilo internacionalnog karaktera, bio je umjetnik s vrlo jakom osobnošću, podrijetlom iz male, brdovite, istočne zemlje, koji je izražavao samu srž, nacionalni temperament ${ }^{\prime \prime}{ }^{10}$

Promatrajući odnos između Meštrovića i „Kozoshe“, moramo uzeti u obzir tri ključna trenutka: osnivanje Udruge arhitekata secesionista 1920., održavanje "Memorijalne izložbe mira" 1922. te veliki potres na području Kanta u Tokiju 1923., o kojemu će više biti riječi u sljedećem poglavlju.

\section{Udruga arhitekata secesionista}

O toj Udruzi u Enciklopediji likovnih umjetnosti piše (skraćeno): „Na Odjelu za kiparstvo Carskog sveučilišta u Tokiju šestero diplomanata vodilo je pokret za modernu arhitekturu, prvi takve vrste u Japanu. (...) Poslije 1914. (...) naglasak se stavljao na potrebu za izgradnjom građevina koje će se moći oduprijeti potresu. Kao reakcija na to osnovana je Udruga arhitekata secesionista, koja je zagovarala sintezu arhitekture i umjetnosti te tražila nova arhitektonska rješenja, različita od prošlih tradicionalnih stilova. Njezini članovi (Kikuji Ishimoto, Sutemi Horiguchi, Masao Takizawa i drugi) bili su jedinstveni, služeći se oblicima poput zakrivljenih linija i površina pod utjecajem njemačkog ekspresionizma. "11

Hakutei Ishii, Hodočašća europske umjetnosti. Prvi dio, Tokio 1913, 226. (石井柏亭、『欧州美術遍 路』上巻、東雲書房、1913年、226ページ)

8 Usp. „Izvješće o umjetničkom svijetu u inozemstvu (2)“, Umjetničke novine, 14/12, 1915, 29. (観堂学 人、「海外美術界時報（二）」、『美術新報』14巻12号、1915年10月、29ページ)

9 Shinpu Takamura, "Izvješće o putovanju kroz Sjevernu Europu“, Središnja umjetnost, 2/4, 1916, 12-16. (高村眞夫、「北欧通過記 (一)」『中央美術』2巻4号、1916年4月、12〜26ページ)

10 San Takeda, „Ivan Meštrović - srpska nacionalnost i umjetnost“, Mjesečni izvještaj udruge Alumni Umjetničke škole u Tokiju, 21/3, 1922, 1-7. (武田粲、「イワン・メストロウィッチ（セルビアの 国民性と芸術）」、『東京美術学校校友会月報』21巻3号、1922年7月、1〜 7ページ)

11 Ryosuke Kita, „Udruga arhitekata secesionista“, artscape.jp/artword (喜多亮介、分離派建築会、artscape. jp/artword) 
Kada govorim o njemačkom ekspresionizmu (koje se može shvatiti kao odraz nečije emocije u prvom planu), mislim na umjetnički pokret u Njemačkoj početkom 20. stoljeća koji je nastao kao reakcija na impresionizam (u kojem je emocija prikazana onako kako je drugi vide).

Radi jasnoće treba napomenuti da se - kao što se koristi u ovom radu - izraz "ekspresionizam" ne odnosi isključivo na bečku secesiju, ali se, umjesto toga, koristi za opisivanje stila koji je široko rasprostranjen u Njemačkoj i drugim europskim zemljama; svojstven je i spomenutoj Udruzi arhitekata secesionista.

\section{„Memorijalna izložba mira“ 1922.}

Poslije Prvoga svjetskog rata „Memorijalna izložba mira“ održana je u Uenu (Tokio). Povoljna strana rata bio je razvoj kapitalizma u Japanu, povećavanje radne snage iz pokrajina te pojačana koncentracija stanovništva u Tokiju. Arhitekt Chuta Ito, glavna odgovorna osoba za organizaciju izložbenog prostora, u namjeri da osmisli originalnu arhitektonsku strukturu unutar tog prostora, povjerio je tu zadaću mladim članovima Udruge arhitekata secesionista.

Kada su počeli raditi na arhitektonskoj strukturi, „pod utjecajem secesije s kraja stoljeća nastalo je djelo jedinstvenog stila, slično ekspresionizmu koji se naglo pojavio u Njemačkoj i Nizozemskoj poslije Prvoga svjetskog rata, čiji je osnovni izraz bio parabola“. ${ }^{12}$ Na primjer, vidljiva je sličnost „Ženidbene kule“ J. M. Olbricha i „Iketa“ („Baklja u vrtnom ribnjaku“) Sutemija Horiguchija; također su se isticali Horiguchijev tehnički te paviljon električnih uređaja. Unutarnji prostor potonjeg nije imao stupove kao potpornje, a izgled mu je ekspresionistički, zbog čega to zdanje poprima avangardnu strukturu.

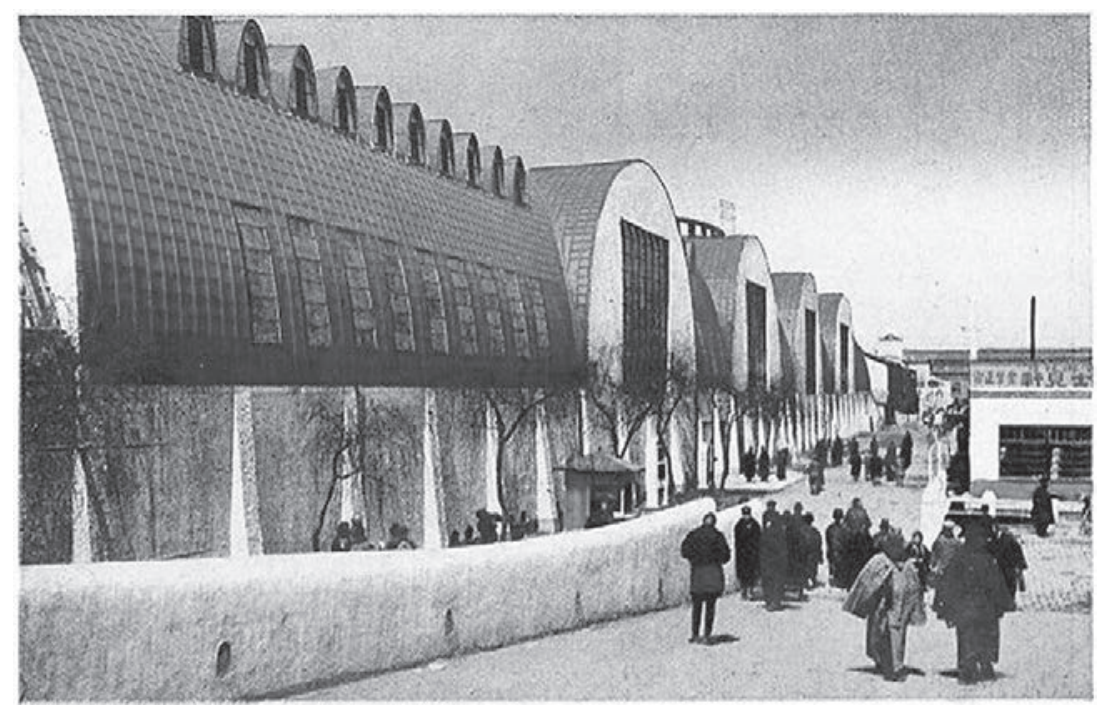

SI. 1. Sutemi Horiguchi, Tehnički paviljon i paviljon električnih uređaja, "Memorijalna izložba mira" (1922.) ${ }^{13}$

12 Yuko Saito, „Studija o 'Kozoshi'“, Geiso, 16, 1999, 47. (斎藤祐子、「構造社」、藝叢第16号、1999 年、47ページ)

13 Izvor: https://suzumodern.exblog.jp/17981196/ 


\section{Japanske publikacije o Meštroviću}

Izdavačka kuća „Koyosha“, koja objavljuje djela vezana za arhitekturu, izdala je 1923. monografiju o Meštrovićevim skulpturama. Godine 1926. isti izdavač objavio je djelo Ivan Meštrović, a nakladnička kuća "Središnja umjetnost“ (Chuo Bijutsusha) knjigu Poslije Rodina, čime je postignut vrhunac Meštrovićeve popularnosti na japanskoj umjetničkoj sceni. Autor djela Ivan Meštrović bio je Morinosuke Suwa, čovjek o kojemu se malo zna, no budući da je njegov pristup temi važan, reći ćemo nešto više o njegovu radu.

Morinosuke Suwa: Ivan Meštrović (Koyosha, 1926.)

Na samom početku knjige Suwa raspravlja o okolnostima zbog kojih naprednim europskim zemljama zaostaje kultura male zemlje, Srbije. Od davnina su u tim planinskim predjelima prevladavali surovi prirodni uvjeti, dok je u prošlosti umjetnost ondje cvjetala. Suwa primjećuje: „Ne mogu se oteti razmišljanju kako je sudbina te zemlje vrlo slična sudbini korejske države. " ${ }^{14}$ Naravno, ako prihvatimo razliku u uvjetima te okolnim zemlja$\mathrm{ma}$ /narodima, obje su zemlje imale razdoblje umjetničkog procvata, ali ono biva ubrzo pokopano u dalekoj prošlosti. Zato Suwa, govoreći o balkanskim zemljama, uspoređuje to područje s Korejom. „Ova narodna umjetnost, legende koje su postojale od pamtivijeka uništene su vandalizmom drugih naroda ili osvajača koji su prekinuli kontinuitet. ${ }^{\text {}}{ }^{15}$

Prema Suwi, Meštrović je živio u takvom podneblju, stoga su u umjetničkom svijetu Hrvati i Srbi zauzeli važno, možda i najvažnije mjesto. Čini se da se Meštrović ne bavi situacijom južnih Slavena, no to ne mora u potpunosti biti točno. Nosi li možda, poput vjetra s planina, poruku o njihovoj nevolji negdje drugdje?

Takav stav, nastavlja Suwa, nije bio pod utjecajem sadašnjih trendova, već se njime iskazuju čežnja i suosjećanje s ljudima s kojima ga od davnina veže ista krv; u nastojanjima da otkrije taj nezaboravljeni svijet, ti su ga ljudi doveli do same granice umjetničkog zanosa, usmjerivši njegov životni put. Potom je, ničim ometan, duboko urezivao korak po korak na tom putu.

Suwa je razmatrao okolnosti koje su utjecale na oblikovanje mladog Meštrovića.

Vjerojatno je najznačajnije bilo znanje i iskustvo stečeno na Akademiji likovnih umjetnosti u Beču. ${ }^{16}$ Sjećanje na djetinjstvo, kada je Meštrović bio pastir, bilo je zametnuto negdje u njegovoj podsvijesti, ali je naposljetku probudilo njegovu čežnju za narodom i narodnim duhom. Zato su akademsko, neformalno prijateljstvo s Rodinom, koji je u to doba već stekao međunarodnu slavu, kao i novi secesionistički pokret označavali samo smjer u kojem se mogao kretati, no Meštrović ni u jednom od tih stilova nije pronašao vlastiti izraz. Naprotiv, duh koji mu je usađen u mladosti oblikovao ga je kao autora i definitivno odredio njegov umjetnički stav.

14 Morinosuke Suwa, „Uvod“, u: Ivan Meštrović, Tokio 1926. (諏訪森之助、『イヴァン・メストロヴィ ッチ』、洪洋社、1926年、序)

15 Ibid., 30-31. (同上、30-31ページ)

Štoviše, Suwa je kao literaturu naveo sljedeća djela: Art and Archaeology, XVII/5, 1924; Deutsche Kunst und Dekoration, XXV/4, 1923; Deutsche Kunst und Dekoration, XXVI/9, 1923; Architectural Record, $57 / 2,1925$.

16 Ibid., 36. (同上、36ページ) 
Zbog takvog pogleda na narodnost i povijest, Suwa tvrdi da se Meštrovića ne bi trebalo smatrati lokalnim nego narodnim umjetnikom. Pored njega, postojala je i skupina lokalnih umjetnika, koji su uglavnom slikali Sloveniju, poznatu po planinskim krajolicima i prekrasnom pejzažu. Ti su lokalni umjetnici, za razliku od Meštrovića, nastojali samo što preciznije slikati krajolik jer su bili naturalisti i impresionisti. Za njihov se put ne može reći da počiva na razvijanju nacionalne svijesti, već je smisao njihovih djela bio podosta drugačiji; podlogu pronalaze u svijetu francuskog impresionizma. Ako tu skupinu nazovemo lokalnim umjetnicima, onda je prikladno Meštrovića nazvati narodnim umjetnikom. „Ako se u djelima prve skupine osjeća čežnja za zemljom, u Meštrovićevim se djelima osjeća čežnja za krvnom vezom. ${ }^{.17}$

Teritorij i krvne veze bili su zapravo glavni problem u stvaranju Jugoslavije. U vidovdanskoj seriji Meštrovićevih skulptura krvna veza bila je mnogo važnija od teritorija.

Govoreći o Meštrovićevim arhitektonskim ostvarenjima, Suwa smatra da je važno ukazati na grobnicu obitelji Račić u Cavtatu. Tvrdi da će svatko zacijelo osjetiti da je u cjelini zamišljena kao organski skladan spoj arhitekture i kiparstva. Što se izraza tiče, očita je njegova velika sposobnost kao kipara, no ako je promatramo analitički, možemo zaključiti da se koristio materijalom karakterističnim za to područje pa u obliku te skulpture možda ima jugoslavenskog duha, kao i vjerskog žara koji gori jakim plamenom. Suwino je divljenje duboko: „Nije pretjerati kazati da je to stapanje, odnosno sklad postignut njegovom majstorstvom. ${ }^{\text {"18 }}$

Skulpture u njegovoj arhitekturi nisu tek puki ornamenti, već se pojedinačno mogu promatrati kao autentična i vrijedna djela. „Doista, nećemo pretjerati ni ako kažemo da je spajanje, odnosno sinteza skulpture kao ornamenta arhitekture te skulpture kao takve postignuto u modernizmu zahvaljujući Meštroviću. ${ }^{.19}$

Kao umjetnik bio je domoljub i vjernik, no istodobno jako su ga zanimale i druge religije. „Primjerice, ponekad na skulpturi nalazimo konkretne linije, koje na kraju uspijeva spojiti, dobivši profinjen umjetnički materijal koji je tražio. ${ }^{\text {"20 }}$

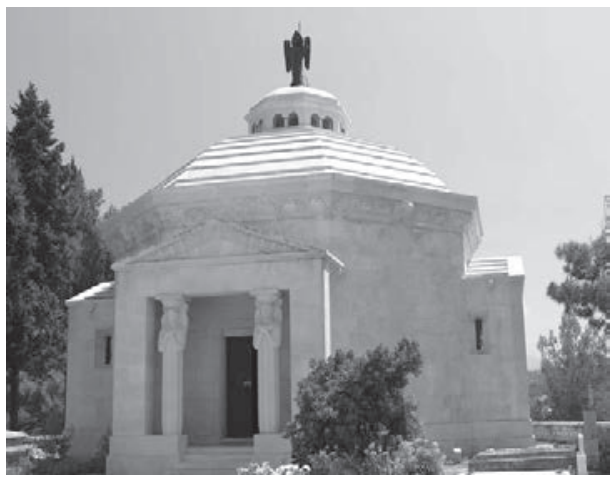

Sl. 2. Ivan Meštrović, Grobnica u Cavtatu (1922.)

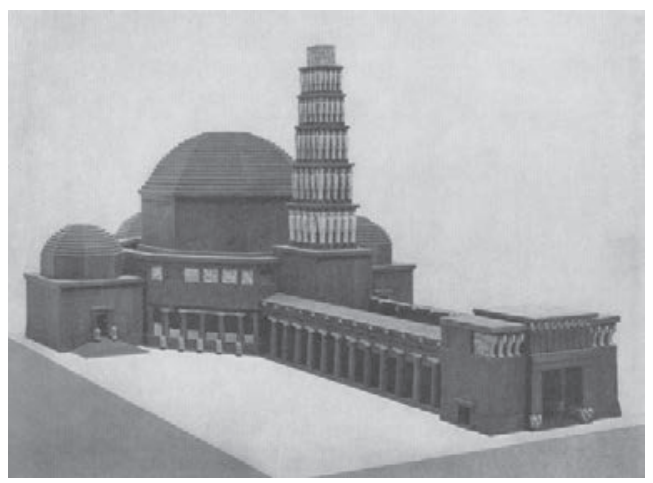

SI. 3. Ivan Meštrović, Vidovdanski hram $(1912 .)^{21}$

17 Ibid., 38. (同上、38ページ)

18 Ibid., 50. (同上、50ページ)

19 Ibid. (同上、)

20 Ibid., 50-51. (同上、50-51ページ)

21 Izvor: Suwa, Ivan Meštrović. (諏訪森之助、『イヴァン・メストロヴィッチ』、洪洋社、1926年) 


\section{Chikatada Kurata: Poslije Rodina (Chuo bijutsusha)}

Arhitekt Chikatada Kurata bio je član Udruge arhitekata secesionista, ali je ujedno proučavao i povijest arhitekture. U djelu Poslije Rodina ovako je pisao o Meštroviću: „Uživam u ostvarenju iznimne moći i energije u njegovim djelima. To uključuje i njegov stariji rad, skicu za slavni kosovski hram, kao i recentniji rad iz 1922. u Cavtatu, blizu Dubrovnika, gdje je dovršena grobnica, u kojoj se ogleda spoj arhitekture i kiparstva. $U$ tom pogledu pokazuje sličnosti s Metznerom. ${ }^{22}$

Kurata je smatrao da Meštrović i Metzner zaslužuju podjednako visoku ocjenu, no budući da se u Japanu malo znalo o Meštroviću, citirao je članak Sutemija Horiguchija iz časopisa Suvremena umjetnost (koji je objavljen šest godina ranije o Meštrovićevoj "Karijatidi“:

Kad sam prije deset godina u časopisu Arhitekt vidio Meštrovićevo djelo, istinski sam se iznenadio, iako moram reći da nisam ljubitelj tog djela. Na objema stranama arhitektonskog zdanja postavljeno je nekoliko ženskih figura, a na kraju zida, razapeta poput paukove mreže, nalazila se skupina žena nalik na sfinge.

No, grčki ženski kipovi koje sam vidio izuzetno su lijepi, ali suviše uski, stoga izazivaju zabrinutost hoće li izdržati težinu koju nose. Meštrovićevi su kipovi bili različiti: žene spuštenih ili uzdignutih ruku imale su blag izraz lica, kao da ih nešto tišti, a srce im razdire tjeskoba kojoj se trude othrvati. Ta se bol, posve prirodno, odražavala na njihovim licima.

Nije bilo nimalo lako proizvesti mješavinu emocija vidljivih na njihovim licima.

No, nije to bilo jedino što me je iznenadilo, već neobična ljepota arhitekture. Bilo je mnogo pojedinačnih skulptura, posloženih u grupi, kao na dramskoj pozornici. (...) Plan je bio posložiti ih u arhitektonskom okviru: svačije lice poprima zastrašujući izraz, no u takvome spoju nastaje ritmički sklad ljepote. Takva se ljepota često viđala u drevnoj religiji. Međutim, ovdje se nije doimala tako staromodnom; u ženskom liku kao potpornju, premda izrađenom u liku sfinge, nije bilo ni daška stila starih majstora. ${ }^{23}$

Kurata je vjerovao da su Meštrovićeva djela prožeta zajedničkom temom: „U svim njegovim djelima izražen je lokalni duh srpskog naroda te je u vječnim potragama za njihovom zemljom bio duboko impresioniran. Kada ih pogledate, osjećate suze i neku primitivnu snagu koja iz njih izvire poput bujice. Bez obzira na to kako se oblik izokretao, on samo odražava snagu autorove osobnosti. ${ }^{24}$

Premda i Suwa i Kurata visoko ocjenjuju Meštrovićev rad, čini se da ga Suwa bolje razumije.

22 Chikatada Kurata, Poslije Rodina, Tokio 1926, 20. (蔵田周忠、『ロダン以後』、中央美術社、1926 年、20ページ)

23 Ibid., 22. (同上、22ページ)

24 Ibid., 21-22. (同上、21-22ページ) 


\section{Osnivanje Društva kipara „Kozosha“. Pokušaj sinteze kiparstva i arhitekture}

\section{Kritika akademizma "Teitena“}

Sogan Saito, koji je u početku bio član žirija za „Bunten“ (izložba umjetnosti Ministarstva obrazovanja), osvojio je 1917. nagradu na "Buntenu“, a od 1923. bio je i član kiparskog odbora za „Teiten“, koji se razvio preoblikovanjem „Buntena”. Godine 1925. došlo je do velikog prekida na "Teitenu“ - od kojega se Saito udaljio - a unutarnji sukobi bili su potaknuti prigovorima postojećoj praksi neprihvaćanja novih talenata.

Izravan uzrok Saitova raskida s „Teitenom“ u studenome 1925. bio je raspad Društva kipara "Todaichosokai“. Godine 1919. Fumio Asakura okupio je mlade kipare-studente Carske umjetničke škole i osnovao društvo. Prva njihova izložba (1921.) ukazivala je na sklad prirode, cvijeća i drveća sa skulpturom, čime se pokušalo razbiti konvencionalni model. Međutim, prema Saitu, „nije malen broj onih koji tvrde za sebe da su umjetnici, a rade za postizanje slave ili zadovoljavanje životnih potreba" ${ }^{\prime 25}$; oni su nametnuli svoje ideje Društvu, napadajući ostale, što je rezultiralo raspadanjem Društva. U pozadini toga sukoba bio je još jedan konflikt između Fumija Asakure i Uichira Ogure, ali treba uzeti u obzir to "neslaganje među umjetnicima te velike razlike u stavovima prema društvenom okruženju“26.

Godine 1927., nakon što se Saito povukao iz "Teitena“ i osnovao Društvo kipara „Kozosha“, u jednom umjetničkom osvrtu izjavio je: „Premda je uključivala brojne članove, starija grupa nije imala precizirano područje rada. 'Teiten' nije bio sposoban ni za što drugo osim niza vrlo trivijalnih djela. ${ }^{27}$ Time je želio ukazati na izniman napor koji je grupa uložila u izbacivanje članova poput Hinaga, Yoa i Ogishime, kao i brojnih drugih talentiranih umjetnika. Kasnije, unutar "Kozoshe“, Yo se usmjerio na obrt, a Ogishima na komercijalnu umjetnost, ali 1923., prije samog raspada, Društvo kipara "Todaichosokai" izbacilo je Yoa, tvrdeći da su njegovi radovi kršili konvencije. Ogishima je stvorio prvu skulpturu manekena u Japanu, no moguće je da ju je Asakura smatrao tek djelom nastalim isključivo radi postizanja zarade. Možda je posljednje u čemu su se slagali Sogan, Hinago i Asakura bio raspored cvijeća i drveća te razmatranje veze između kiparstva i arhitekture.

Hinago je nastojao pronaći načine kako bi slobodnije postigao sintezu kiparstva i arhitektonskih struktura, povezujući ih sa sportskom umjetnošću; htio je izraditi spomenike, kao i medalje za postignuća na raznim poljima. U spomen na katastrofu potresa, Hinago je 1924. na izložbi prezentirao rad kojim je ukazao na potrebu za obnovom metropole. Kipari poput Hinaga i Saita radili su na izradi arhitektonskih spomenika i struktura kojima se nastojalo obilježiti sjećanje na razne katastrofe. Jedan od njih, Hinagov "Toranj smrti“, bio je pravo arhitektonsko remek-djelo koje ukazuje na povezanost s njegovim kasnijim radom, tornjem zvanim "Osam uglova svijeta“.

25 Usp. Toshikazu Hirota, Svijet Jitsuza Hinaga, Tokio 2008, 26. (広田肇一、『日名子実三の世界』、思 文閣出版、2008年、26ページ)

26 Izložba „Kozoshe", Tokio 2005, 14. (構造社展、キュレイターズ、2005年、14ページ)

27 Sogan Saito, „'Kozosha' je rođena“, Atelje, 4/9, 1927, 83. (斎藤素岥、構造社生る、『アトリエ』4 巻9号、1927年9月、83ページ) 


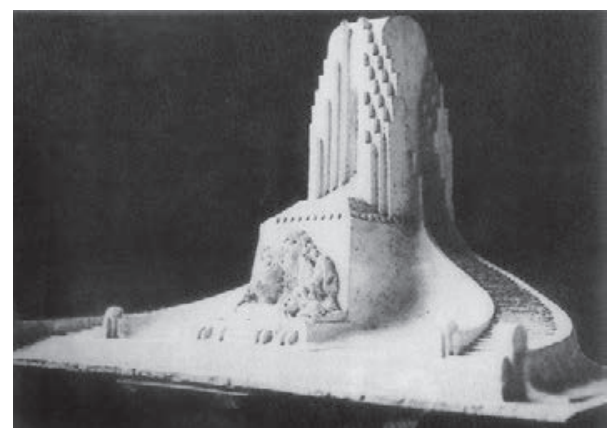

Sl. 4. Jitsuzo Hinago, "Toranj smrti“ (1924.) ${ }^{28}$

\section{Osnivanje Društva kipara „Kozosha“ i japansko društvo}

Osnivanje "Kozoshe“ 1926. pokrenuli su akademski nekonformisti Hinago i Saito, no neposrednim povodom bili su "Memorijalna izložba mira“ te jačanje društvene svijesti umjetnikâ poslije velikog potresa u Tokiju.

\section{„Memorijalna izložba mira“ poslije Prvoga svjetskog rata: arhitektura i kiparstvo}

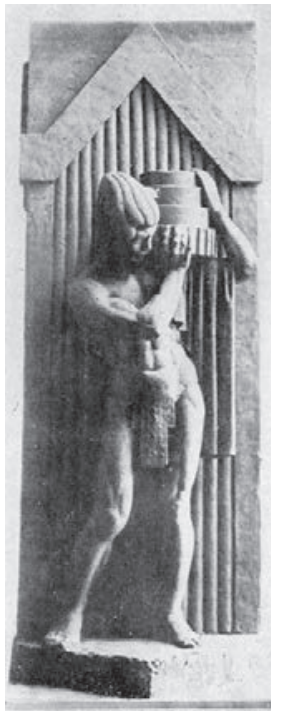

SI. 5. Eisaku Hasegawa, "Kip muškarca" (1922.) ${ }^{31}$

Arhitekt Mamoru Nakamura ocijenio je djela na toj izložbi na sljedeći način: „Koristeći se znanjem o arhitekturi modernizma, mladi su arhitekti u svojim djelima vješto kombinirali arhitekturu i kiparstvo. To je dobar recept i za buduće arhitekte i kipare“. ${ }^{29}$

Saitova kritika skulptura Eisakua Hasegawe koje prikazuju muškarca i ženu, izloženih u tehničkom paviljonu, glasila je: „Nabori tkanine i dlakama obrasla mjesta, oblikovani slično kao u Meštrovićevu djelu, ostvareni su na jednostavan način ${ }^{430}$, dodajući kako se na tim skulpturama osjeća Meštrovićeva snaga izražavanja.

Otada se u arhitekturi javljaju nova kretanja. $U$ to je vrijeme urbana arhitektura u Tokiju bila u punom zamahu te se iznenada pojavila potreba za novim pogledom na arhitekturu, a ta je tendencija sve više rasla. Međutim, kiparstvo je, kao i prije, uglavnom bilo usmjereno na realističke aktove, portrete i slično, ne izlazeći izvan tih granica.

28 Izvor: Hirota, Svijet Jitsuza Hinaga, 34. (広田肇一、『日名子実三の世界』、思文閣出版、2008年、34 ページ)

29 Y. Saito, „Studija o 'Kozoshi'“, 52. (斎藤祐子、前掲論文、52ページ)

30 Isti, „Kritika skulpture na 'Memorijalnoj izložbi mira' (nastavak)“, Yomiuri Shinbun, 28. 3. 1922. (斎藤素 嚴、「平和博の彫刻を評す（下）」、『読売新聞』、1922年3月28日付)

31 Izvor: Eisaku Hasegawa, Uvod u plastičnu umjetnost, Tokio 1927, 62-63. (長谷川栄作、『彫塑の手ほ どき』、博文館、1927年、62-63ページ) 
Veliki potres u Tokiju, osnivanje Društva kipara "Kozosha“ $i$ „skulpturâ za društvo“

Godine 1923. dogodio se veliki potres na području Kanta u Tokiju. Izgradnja privremenih baraka koja je uslijedila predstavljala je ogroman pothvat, zbog čega dolazi do procvata ornamentacije u arhitekturi. Poslije masakra Korejaca ( $U$ vrtlogu potresa ubijeni su korejski Japanci i stanovnici koje se pogrešno smatralo Korejcima. Točan je broj žrtava nepoznat; procjenjuje se da ih je bilo od jedne do nekoliko tisuća.) i slučaja "Osugi“ (u kojemu je policija ubila poznatog anarhista Sakaea Osugija tijekom nereda koji su izbili nakon potresa) prevladavalo je stanje nesigurnosti. $U$ takvim su okolnostima umjetnici - bez obzira na stil ili dob - koji su bili zabrinuti za budućnost, služeći se vlastitim umijećem, željeli stvarati djela kako bi mogli zarađivati. ${ }^{32}$ Međutim, Hinago je bio više opčinjen strukturalističkim dijelom arhitekture nego samim ornamentima, što može biti povezano s nazivom "Kozosha" (kozo = 'struktura', sha = 'društvo'). Kipar i pjesnik Kotaro Takamura smatrao je da naglasak treba staviti na strukturu, što je istaknuo u članku „Deset klauzula kiparstva“ (1926.); vrlo je vjerojatno Sogan Saito bio upoznat s tim konceptom. ${ }^{33}$

Godine 1924. na izložbi nacrtâ za obnovu metropole Hinago je započeo s radom na "Tornju smrti“, a Saitovo djelo "Grob“, izloženo 1923. na 2. izložbi „Todaichosakai“ u Tokiju, pokazalo je jasnu orijentaciju prema arhitekturi. Naposljetku su Saito i Hinago, stremeći k sintezi arhitekture i kiparstva, 1926. osnovali Društvo kipara "Kozosha“. U svojem članku „Skulptura kao primijenjena umjetnost“ (1928.) Saito zagovara ideologiju "Kozoshe" te iznosi kritički stav prema standardnom obrazovanju koje je pružalo samo ograničeno znanje o spajanju arhitekture i kiparstva te o izradi medalja.

Tekst Saitova manifesta prilično je dugačak, stoga se navodi u sažetom obliku s ključnim elementima:

Kao stvar vrijedna razmatranja, u Japanu se primijenjeno kiparstvo razvijalo nepravilno. Polovična se krivnja za to može pripisati učiteljima umjetnosti jer leži na njihovim pogreškama.

Jednostavno rečeno, kiparsko se umijeće $u$ inozemstvu stječe izradom kopija klasičnih djela ili, pak, majstorskih djela iz razdoblja modernizma. Radi se o proučavanju ljudskog tijela, kao što je to istaknuto u Japanu, ali pristup temama i metodama modeliranja otkriva razinu neprozirnosti, po čemu se razlikuje od japanskog pristupa. Uočava se veza s arhitekturom, kompozicije koje ne uključuju samo skulpture s temom golih tijela već i one s odjećom. Takve kompozicije, zbog nabora na odjeći, različitih pojedinačnih stilova, kao i grupnih skulptura, umjetnicima zadaju glavobolju (...), stoga će se ta pitanja još morati rješavati.

Ono što nam preostaje jest rad na zakrivljenim površinama i reljefu, kao i na bilo kojoj vrsti izravnog kontakta s arhitektonskom ornamentacijom, tj. s drvenom obradom jer je to početnički korak prema klesanju, ali (...) pritom mislim, naravno, i

32 Usp. Toshiharu Igarashi, Studij umjetničkog pokreta nastalog u "Taisho“ razdoblju/revidirano izdanje/, Tokio 1998，292-300. (五十嵐利治『大正期新興美術運動の研究』改訂版、スカイドア、1998年、292 〜300ページ)

33 Usp. Hirotake Kurokawa - Tomomi Omura (ur.), Djela Sogana Saita, Tokio 2007, 30. (黒川弘毅 - 大村 友美編、齋藤素巖の仕事 : 共同研究「小平市所蔵齋藤素巌遺作研究と作品の保存・活用につい て」、武蔵野美術大学彫刻学科研究室、2007年、30ページ) 
na metalnu skulpturu. Proučavajući raznolikost materijala, mladi kipar traži onaj koji najviše odgovara njegovim potrebama i nastavlja s njim raditi kad ga odabere.

U Japanu radilo se samo na modeliranju golih tijela; nije se učilo ili radilo i na drugim vrstama kompozicija ili, točnije, nije bilo stručnjakâ koji bi mogli prenijeti takvo znanje. Da je netko svladao potrebno znanje, mogao je isklesati tijelo (...) Međutim, zbog nedostatka znanja u izradi ornamenata, ne bi mogao napraviti skulpturu koja bi primjenom ornamenata izgledala poput umjetničkog djela.

Najbolji su primjeri skulpture „Teitena“ koje, nažalost, to dokazuju. One uzalud lutaju, a oči društva okrenule su se od njih te im je namijenjena sudbina skorog pada u zaborav i odbacivanja. (...) Gušenje talenata, koji bi se inače bezgranično razvijali, ispravljanje njihova „prokletstva“ i prisilno svođenje na jedinstveni kalup djeluje poput zagovaranja opće ljudske slabosti. ${ }^{34}$

U obzir valja uzeti i slogan „Kozoshe“: „skulptura kao primijenjena umjetnost", koji je bio jedan od ciljeva u težnji za strukturom.

\section{„Kozosha“: koautorsko djelo. Razlike u odnosu na bečke secesioniste}

I Tokio i Beč bili su usmjereni na na sintezu arhitekture i kiparstva te im je zajednička potraga za temom prikladnom za ostvarenje toga spoja. Na 23. izložbi bečkih secesionista skulptura „Beethoven“ Maxa Klingera ocijenjena je najuspješnijim djelom.

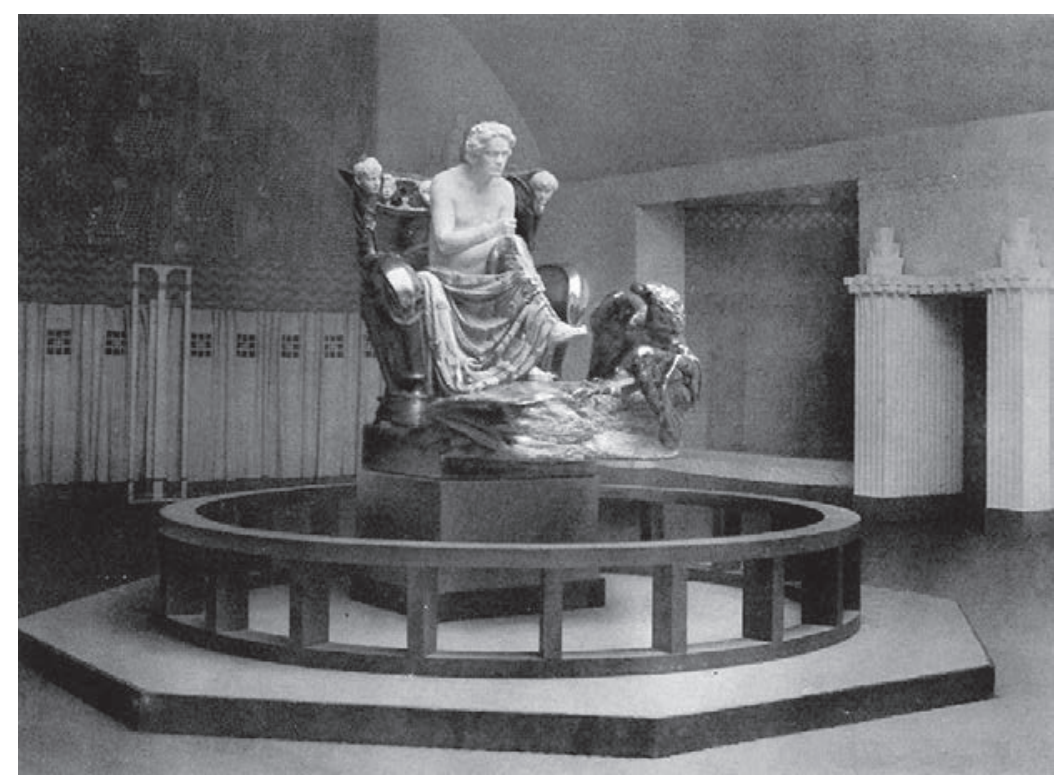

Sl. 6. Max Klinger, "Beethoven“ (1902.) ${ }^{35}$

34 S. Saito, „Skulptura kao primijenjena umjetnost“, Yomiuri Shinbun, 6. 9. 1928. (斎藤素嚴「彫刻の実際 化」読売新聞『読売新聞』、1928年9月6日付)

35 Izvor: http://www.medienkunstnetz.de/works/beethoven/ 
Klinger je bio kipar, a ujedno i teoretičar umjetnosti; pisao je ne samo o pojedinačnim djelima nego i o okolnostima, s naglaskom na stanje u umjetnosti u kojemu su ona nastala. Njegovi tekstovi bili su uvršteni u katalog izložbe. ${ }^{36}$ Jedan je teoretičar istaknuo: „Klinger ne bi prihvatio ništa manje od idealnih uvjeta za nastanak memorijalnog umjetničkog djela. ${ }^{137}$ Međutim, djelo se može vrednovati na razne načine: prvo, na razini sinteze sa samim materijalom; drugo, razmatranjem uloge prostora kao svetišta; treće, kao sinteza i s drugim umjetničkim područjima, kao što je npr. glazba. ${ }^{38}$

O eksperimentalnom radu "Kozoshe“ arhitekt i autor knjige Poslije Rodina, Chikatada Kurata, rekao je da je riječ samo o površinskoj ornamentaciji, u kojoj nema one ideje koja bi ukazivala na arhitekturu te zahtijevala bolje i dublje razumijevanje tog područja. To gledište ima podlogu u racionalističkoj ideologiji modernizma. No, s druge strane, Kenji Imai, arhitekt koji je bio dobro upoznat sa stanjem u Sjevernoj Europi, o umjetnicima „Kozoshe“ imao je drugačije mišljenje: „Društvo 'Kozosha' zaista pokušava razumjeti razvojni proces arhitekture. ${ }^{\prime 39} \mathrm{U}$ Švedskoj je u tim godinama težište bilo na tradicionalnim i kulturnim okolnostima pa se arhitektura razvijala u nacionalno-romantičkom stilu. Drugim riječima, s gledišta modernog racionalizma, "Kozoshino" eksperimentalno djelo opisano je kao trivijalno, dok se u romantizmu, odvojenom od racionalizma, uočava "razvojni entuzijazam".

Ustvari, među glavnim kiparima "Kozoshe“ mogu se uočiti različite težnje. Orijentalni duh izvire iz prvog eksperimentalnog djela Kanjija Yoa na 3. izložbi "Kozoshe“. „Njegova potraga za azijjkim stilom označavala je razumijevanje arhitekture Chute Ita. ${ }^{“ 40} \mathrm{Na}$ sljedećoj, 4. izložbi „Kozoshe“ Hinago je predstavio djelo koje je uključivalo „mnogobrojne zakrivljene površine što podsjećaju na bečki i japanski secesionistički stil, posebno na rad Mamorua Yamade ${ }^{\prime 4}$.

Na 3. izložbi "Kozoshe“ Saito, Yo i Hinago postavili su ulaz u ono što se nazivalo hramom umjetnosti (s pticama i cvijećem na vrhu te štitovima za obranu od zla s obiju strana, kao u pravom hramu). Kritičar Hidenobu Kamiizumi pohvalio je to djelo, uspoređujući ga s „Beethovenom“, ali je iznio i otvorenu kritiku: „Sklad arhitekture i kiparstva ne može se očekivati bez jasnog definiranja teme. Razumijevanje različitih ideja preduvjet je postizanja harmonije. ${ }^{42}$

Nasuprot tome, skulptura "Doba atletike“, "sintetično djelo“ izloženo na 4. izložbi, uspješno izražava popularnost atletike tog razdoblja. ${ }^{43}$

\footnotetext{
36 Usp. Ikeda (ur.), Zapadni suvremeni grad i umjetnost 4, 242. (池田祐子編、 前掲書、242ページ参 照)

37 Ibid. (同上。)

38 Ibid., 244-245. (同244-5ページ参照)

39 Izložba „Kozoshe", 46-47. (構造社展、前掲書、46-7)

40 Ibid., 47. (同上、47ページ)

41 Ibid., 48. (同上、48ページ)

42 Ibid., 24. (同上、24ページ)

43 Ibid., 25. (同上、25ページ参照)
} 


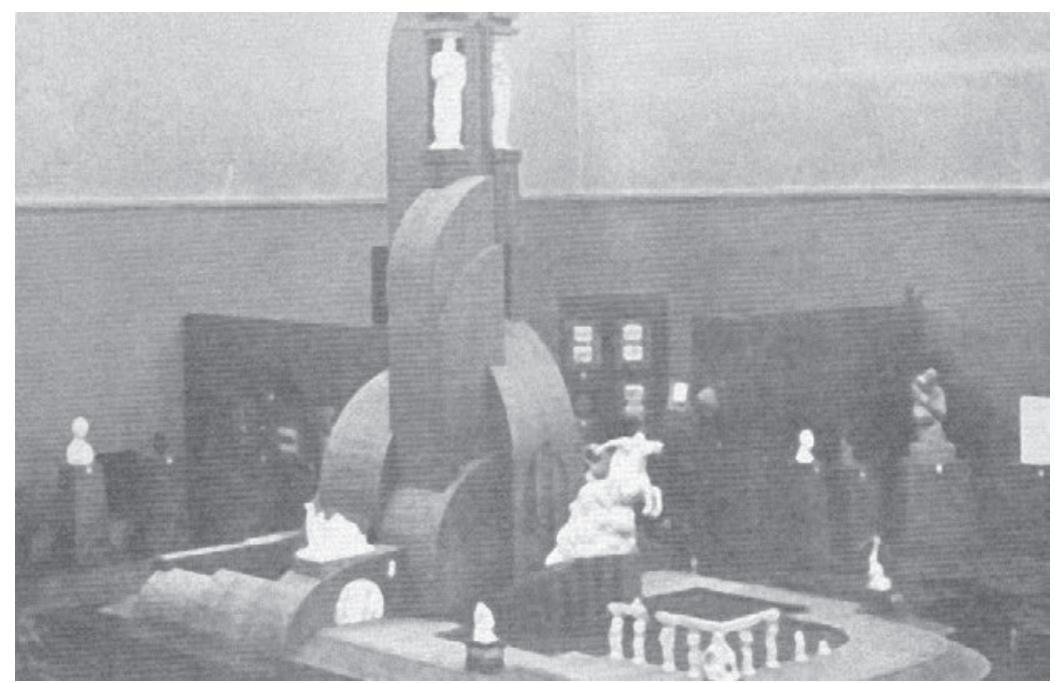

SI. 7. „Sintetično djelo" na 4. izložbi "Kozoshe“: spomenik „Doba atletike" (1930.).44

Kipari „Kozoshe“ odabrali su veliku temu i odlučili izgraditi monumentalnu strukturu, što je uključivalo potporne stupove kao figure, površine zidova ukrašene reljefom i sl.; posao je bio podijeljen te se radilo u sekcijama. Upravo je to, prema jednom kritičaru, pridonijelo nedostatku koherentnosti i snage..$^{45} U$ stvarnosti bilo je teže postići da više autora različitih osobnosti djeluju kao jedinstvena cjelina, kao što se u početku predviđalo. Taj je projekt označio kraj koautorskih djela. Na 5. izložbi "Kozoshe“ naziv "koautorski rad“ zamijenjen je nazivom "sintetično djelo“. Hinago je tvrdio: „Napredovali smo korak dalje od eksperimentalnog razdoblja. Sada će isto djelo na jednak način raditi dva ili tri autora, ili samo jedan." ${ }^{46}$ I dalje se nastavilo sa stvaranjem zajedničkih djela, ali u manjem opsegu, a dinamičnost biva izgubljena. Više nije postojala ona nit koja je činila samu bit zajedničkog djela. Problem nije predstavljalo samo neslaganje u opredjeljivanju za stil koji bi bio najprikladniji za odabranu zajedničku temu (primjerice, racionalizam ili romantizam) nego i financijski razlozi, o čemu će se kasnije više raspravljati.

\section{Kasniji razvoj „Kozoshe“: razlike između kiparâ, naroda i države}

U razdoblju japanske povijesti od kraja Prvoga (1918.) do početka Drugoga svjetskog rata (1941.) uočava se neka vrsta jaza. Poslije Prvoga svjetskog rata Japan je doživio vojno-ekonomski procvat. No, samo dvadeset godina kasnije opstanak države bio je u opasnosti.

44 Izvor: Izložba „Kozoshe”, 24. (構造社展、キュレイターズ、2005年、24ページ)

45 Usp. Hoshu Takamura, „Bilješke o izložbi 'Kozoshe““,Atelje, 7/10, 1930, 103. (高村豊周、構造展覚え 書、『アトリエ』7巻10号、1930年10月、103ページ)

46 Jitsuzo Hinago, „Stvaranje spomenika odanog duha“, Zemlja ljepote, 7/9, 1931，19. (日名子実三「忠 魂碑の製作」『美之国』7巻9号、1931年9月、19ページ) 
Iz "Kozoshe“, osnovane 1926., odvojio se 1944. ogranak kipara. "Kozosha“, čija je djelatnost bila više usmjerena na društvo nego na državu, nakon 18 godina ponovno otpada pod utjecaj države. Među članovima bilo je i onih koji su služili državi.

U okviru rasprave razmotrit ćemo kretanja unutar "Kozoshe“, stavljajući ih u kontekst cjelokupne japanske umjetnosti, kao i iskustva osnivačâ toga Društva, Sogana Saita i Jitsuza Hinaga. Kako bismo bolje razumjeli promjene koje su se odvijale u 18-godišnjem razdoblju, proučit ćemo djela Kanjija Yoa te njihovu povezanost s djelima Ivana Meštrovića.

\section{Rodinov utjecaj: akademizam i odnos prema društvu. Kretanja u „Kozoshi“}

Kraj Prvoga svjetskog rata označio je prekretnicu u svijetu japanskog kiparstva. Godine 1917. umro je Rodin, ali je njegov stav prema kiparstvu snažno utjecao na Japan. Vrativši se sa studija u Francuskoj, kipar i pjesnik Kotaro Takamura preveo je s francuskog jezika knjigu Rodinov izraz (1916.), a već je 1920. objavio i njezin nastavak. Knjiga je ubrzo postala "svojevrsna Biblija za mlade ljude koje je zanimalo kiparstvo“47.

\section{Kretanja u okviru „Kantena“ (državne izložbe) i u nekonformističkim grupama}

Godine 1919., poslije završetka Prvoga svjetskog rata, „Bunten“ (izložba pod pokroviteljstvom Ministarstva obrazovanja) promijenio je naziv u "Teiten“ (izložba pod pokroviteljstvom Carskog instituta za umjetnost), a i u sastavu žirija bilo je mnogo novih lica. Jedan od njih, Taimu Tatehata, postao je 1920. profesor na Umjetničkoj školi u Tokiju. Već su sljedeće godine u istu školu kao profesori došli i Fumio Asakura te Seibo Kitamura. „To je bilo razdoblje zrelog izraza sve trojice; bili su uključeni u 'Kanten' te su još uvijek bili dijelom glavne struje čija se ideologija oslanjala na čvrste skulpture ljudskog tijela“. ${ }^{48}$

Međutim, i unutar te struje kasnije izbijaju žestoki konflikti koji su podijeljeni na tri vrste. Prvi sukobi, osobne naravi, dogodili su se između skupine okupljene oko Fumija Asakure te svih ostalih. Druga je vrsta uključivala sukob mišljenja o važnosti skulpture u odnosu na plastičnu umjetnost, pri čemu se postavljalo pitanje čemu bi trebalo dati prednost, dok je treći bio generacijski sukob. Takve su frakcije unutar glavne kiparske struje utjecale na osnivanje "Kozoshe".

lako nisu bile izravno povezane s „Kozoshom“, postojale su i druge, nevladine udruge, kao što su Nihon-bijutu-in, Nika-kai i Kokugo-kai. Bile su pod značajnim Rodinovim utjecajem te se u njihovim djelima osjeća umjetnički duh svojstven ne samo potonjem nego i Bourdelleu. Unutar tih strujanja oblikovao se japanski stav prema modernom kiparstvu, što je nesumnjivo omogućavalo njegovo bolje razumijevanje. Osim Rodinova utjecaja, sklonost povezivanju s „prirodnim aspektima života“ također je pridonijela formiranju japanskoga gledišta. To se, uostalom, nadovezivalo na bogatu japansku tradiciju budističkih skulptura. Međutim, postavlja se pitanje treba li se japansko kiparstvo „ograničiti samo na te tradicionalne tendencije ${ }^{\mu 49}$. $U$ Japanu, primjerice, ideja o apstraktnom ekspresionizmu počinje poprimati razvojni oblik tek poslije Drugoga svjetskog rata. Treba uzeti u obzir mogućnost

47 Kazuo Kikuchi, Rodin, Tokio 1968, 10. (菊池一雄『ロダン』中央公論美術出版、1968年、10ページ)

48 Izložba "Kozoshe", 12. (構造社展、前掲書、12ページ)

49 Ibid., 15. (同上、15ページ) 
da se u prijeratnom razdoblju nisu javljali pravci bliski apstraktnom ekspresionizmu jer nije prevladavalo shvaćanje da ljudsko tijelo može biti konceptualna osnova za skulpturu.

\section{Kretanja unutar „Kozoshe“}

Godine 1932., prvog dana 6. izložbe „Kozoshe“, njezina vodeća osoba Sogan Saito povukao se iz Društva. Od tog vremena nadalje „Kozosha“, koja se dotad dičila dobrom organizacijom i prosperitetom, počinje pucati po šavovima. Razlozi Saitova povlačenja bili su financijske prirode jer je preuzeo odgovornost svih troškova. Kasnije, zbog unutarnjih sukoba, povukla su se još trojica članova: Jitsuzo Hinago, Miezo Shimizu i Sadayuki Ameda. Tada je donesena odluka o privremenom raspuštanju "Kozoshe“ te je preimenovana u Novo društvo "Kozosha", nastavljajući s radom, no već iduće godine, nakon Saitova povratka, ponovno postaje Društvo "Kozosha”.

Godine 1935., Saitovim povratkom na "Teiten“, „Kozosha“ se počela raspadati. Već je sama činjenica da se čovjek koji se prvi pobunio protiv akademizma te osnovao i uzdignuo "Kozoshu“ na zavidnu razinu „,ratio" akademizmu šokirala članove toga Društva. Njihovo javno priopćenje s time u vezi glasilo je ovako:

U svibnju ove godine (1935.) došlo je do reorganizacije na Carskoj akademiji i za novog člana "Teitena“ izabran je Sogan Saito. Međutim, to se dogodilo kada se „Teiten“, koji se našao u slijepoj ulici, u suradnji s drugim nevladinim udrugama i uz pristanak vlasti, pokušao reorganizirati, no to ni na koji način nije značilo da je "Kozosha" promijenila dotadašnji koncept i stavove (...). ${ }^{50}$

Ubrzo su izbile nesuglasice između brojnih članova "Kozoshe“ (Saito, Yo, Saburo Hamada i drugi) i Odjela za kiparstvo, stoga se potonji našao u ozbiljnoj situaciji. Naposljetku, iako je na tom Odjelu ostalo svega deset članova, odnos sa Saitom postajao je sve složenijim, što je u konačnici dovelo do podjele na dva odjela: Odjela za kiparstvo i Odjela za likovnu umjetnost.

Iz Odjela za likovnu umjetnost formiralo se 1936. Novo društvo „Kozosha“, koje postoji i danas. Na Odjelu za kiparstvo održavali su samo vlastite izložbe, a 1944. konačno je raspušten. Najbolje razdoblje "Kozoshina" djelovanja bilo je "doba sinkretičkih djela te stapanje kiparskih i obrtničkih radova, odnosno početno razdoblje 'Kozoshe', kada je u sklopu nje još uvijek djelovao Hinago ${ }^{\prime 51}$. Godine 1935., s obzirom na to da je Saito prihvatio dužnosti slijedom reforme "Teitena“ (tzv. „reforma Matsuda“), „Kozosha“ je izgubila svojega najvažnijeg člana, što je označavalo veliku prekretnicu. Saito je, s druge strane, okupio najbolje kipare među onima čiji radovi nisu bili predani žiriju, ukinuvši kvalifikaciju za izlaganje bez testiranja. Time je samo htio postaviti kipare u položaj u kojemu bi mogli neovisno djelovati, a ne iskazati pobunu protiv same Carske akademije.

„Kozosha“ je u nastojanjima da postigne sintezu kiparstva i arhitekture odigrala važnu ulogu. Taj je oblik rada započeo unutar tog Društva, a tako je i završio, ne proširivši se dalje. Tridesetih godina 20. stoljeća pojavljuje se Le Corbusier, a s njime i nova, modernistička

50 Shigeru Aoki (sastavio), Nacionalni institut za istraživanje kulturnih dobara u Tokiju, (Komentar) Shuji Tanaka, Moderna japanska umjetnost - Katalog - Kiparstvo, Kozosha/Shinkozosha, Tokio 2008, 149. (監 修］青木茂 [編纂］東京文化財研究所［解説］田中修二、近代日本アート・カタログ・コレクシ ヨン 彫刻篇 構造社・新構造社、ゆまに書房、2008年、149ページ)

51 Izložba „Kozoshe”, 122. (構造社展、前掲書、122ページ) 
arhitektura, u kojoj, zbog jednostavnosti gradskih središta i trgova, više nije bilo potrebe za skulpturama ili arhitektonskom dekoracijom. Kao što primjećuje jedan povjesničar: „Nije važno je li njihov rad bio uspješan ili ne, nego to da je 'Kozosha', zahvaljujući svojem djelovanju, svijetu kiparstva toga vremena podarila novu svijest. ${ }^{452}$

\section{Kanji Yo: rani utjecaj i kasniji otklon od Meštrovića}

Kanji Yo rodio se 1898. u Tokiju; njegov predak bio je prevoditelj za Kinu. Njegovo djelo koje je predstavio na izložbi „Buntena“ 1918. dobilo je nagradu 1. izložbe „Teitena“; počevši od 1919., nekoliko godina zaredom primao je nagrade, a 1922. za svoj je rad dobio posebno priznanje. Jedan kritičar toga doba u njegovim je djelima uočio Meštrovićev utjecaj: „Rezbarenje je vrlo djelotvorno, u funkciji ukrasa i bez suvišnoga gubitka materijala. Među europskim umjetnicima mogli bismo ga usporediti sa srpskim kiparom Ivanom Meštrovićem, čiji se utjecaj osjeća (...) u jednostavnosti i snazi izražavanja, izravnom osjećaju veličine te odgovarajućoj primjeni tehnike (...). ${ }^{43}$ Kritičar dodaje: „Yo nije posvećivao previše pozornosti detaljima, već je svojoj skulpturi htio podariti život, udahnuti joj duh a da pritom ostane što jednostavnijom".

Na 6. izložbi „Teitena“ 1925. Yoovo djelo „Trojica nezaposlenih“ odražava zaobljene linije secesijskog (Art Nouveau) stila. To se kasnije uočava i na skulpturi „Saloma“ (1928.), no glede detalja koji su svedeni na najmanju moguću mjeru nema promjene. „Napušten je volumen; na površini izložene su elegantne zaobljene linije, a k tome je uložen izniman trud kako bi se postigla glatkoća. ${ }^{\text {"54 }}$ Kada je Yo razriješio sumnje o volumenu, smatra likovni kritičar Masayoshi Honma, izišla je na vidjelo istinska ljepota djela. Salomine noge i dalje zadržavaju punoću, ali je čitava figura prilično izdužena i tanašna. ${ }^{55}$

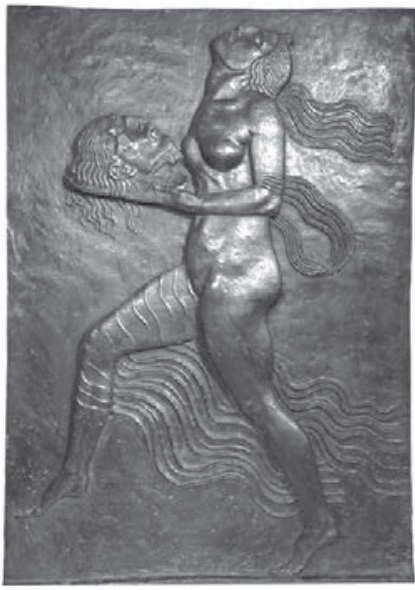

Sl. 8. Ivan Meštrović, "Saloma" (1914.) $)^{56}$

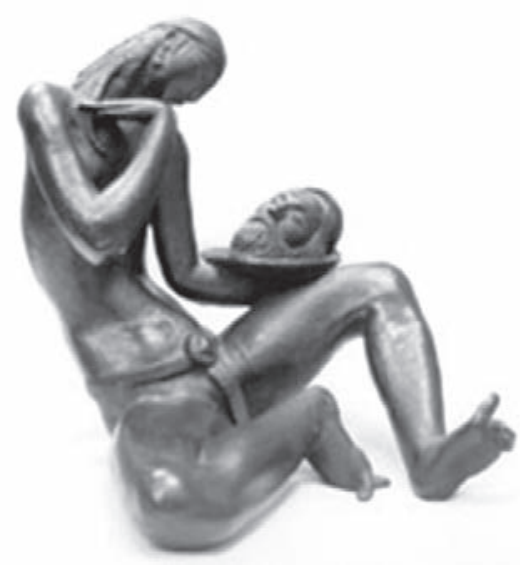

Sl. 9. Kanji Yo, "Saloma" (1928. $)^{57}$

\footnotetext{
52 Ibid. (同上)

53 Koji Tanabe, „Osvrt na skulpturu 'Teitena'“, Yamato Shinbun, 13. 10. 1922. (田辺孝次、帝展の彫刻評、 大和新聞、1922年10月13日付)

54 Izložba „Kozoshe", 261. (構造社展、前掲書、261ページ)

55 Ibid., 263. (同上、263ページ参照)

56 Izvor: https://www.fine-arts-museum.be/nl/de-collectie/ivan-mestrovic-salome

57 Izvor: http://archive.fo/KXrfa
} 
Yoova "Saloma“ može se usporediti s tematski jednakim djelom Ivana Meštrovića. Dok se Meštrović služi volumenom kako bi u svojim djelima izrazio žalosnu sudbinu svojega naroda, You volumen ne služi za izražavanje osjećaja (poput tuge), stoga odbacuje njegovu funkciju kao takvu. ${ }^{58}$ Dodavanjem dekorativnih elemenata u stilu Art Deco zaobljenoj liniji secesije ili "nove umjetnosti“ (Art Nouveau), na kojoj se zapravo temelji japanska umjetnost, poigravajući se kombinacijom ornamenata i ravne površine, Kanji Yo unio je japanski izraz u zapadnjačku temu te time stvorio neobičnu, originalnu skulpturu. ${ }^{59}$

Glede značenja volumena u Yoovim djelima, očigledan je otklon od Meštrovića. No, zajednička su im stajališta o traganju za nacionalnim izrazom i o tim karakterističnim elementima u čeških i hrvatskih umjetnika secesionističkog pokreta. (Kao što ćemo kasnije spomenuti, Jitsuzo Hinago također je tražio nacionalni izraz.)

Za usporedbu Yoa i Meštrovića značajan je posmrtni tekst kojim se od Yoa oprašta njegov kolega. Kanji Yo umro je 1935., u 37. godini života, zbog bolesti dišnih organa. Saburo Hamada, također "Kozoshin" "drug", koji je bio pod utjecajem Maillola i Meštrovića, zapisao je: „Tvoj realistički stil, u kombinaciji s esencijalnom prirodom skulpture, pridonosi stvaranju karakterističnog orijentalnog izraza. (...) Od 'Zapada i Istoka' ili, točnije, Edo stila, pod tvojim rukama nastaje zamršena simfonija. ${ }^{\prime 60}$

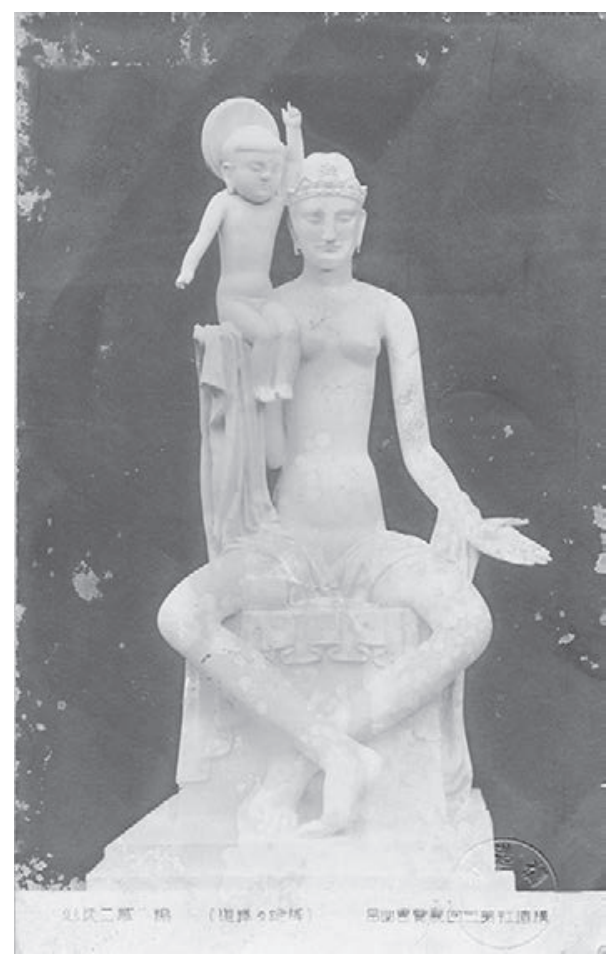

Sl. 10. Kanji Yo, „Inkarnacija Bude“ (1929.) ${ }^{61}$

58 Izložba „Kozoshe“, 266-267. (同上、266-7ページ参照)

59 Ibid., 267. (同上、267ページ参照)

60 Aoki, Moderna japanska umjetnost, 188. (近代日本アート・カタログ・コレクション、前掲書、188ペー ジ)

61 Izvor: 


\section{Jitsuzo Hinago: djelovanje tijekom Drugoga svjetskog rata}

Jitsuzo Hinago rodio se 1893. u Oiti. Godine 1918. upisao je Umjetničku školu u Tokiju koju je završio kao najbolji u razredu, a iduće godine sudjelovao je na izložbi „Teitena“. Međutim, nije dobio nagradu pa je kasnije svoj rad, preporučen za "Teiten“, izložio bez podvrgavanja testiranju žirija. Hinago, koji se 1932. povukao iz „Kozoshe“, već se 1933. vratio na "Teiten“ kad ondje nije bilo Asakure. No, kad se potonji 1935. onamo vratio, Hinago je pod sloganom „Dolje akademski stil!“ osnovao Udrugu "Daisan-bukai“. Neprijateljstvo koje je osjećao prema Asakuri trajalo je do kraja njegova života. Pretpostavlja se da se "Hinago se nije mogao zadovoljiti Asakurinim naturalističkim realizmom, niti je takav stil odgovarao njegovu karakteru“62. Međutim, sukob između Asakure i Hinaga bio je zapravo sukob generacija i njihovih nastojanja da pronađu vlastiti umjetnički stil. Kasnije je, kao suprotnost "Teitenu“ i Asakuri, toranj „Osam uglova svijeta“, Hinagovo reprezentativno djelo, bilo izloženo na trgu (danas Heiwadai-koen park u Miyazakiju), odnosno javnom prostoru kao javno umjetničko djelo. ${ }^{63}$

Od 1926., kada je osnovana "Kozosha“, do 1932., kada se Hinago povlači, pa sve do njegove smrti 1945., za potonjega je karakterističan emocionalan pristup društvu i narodu. Godine 1925. organizirao je izložbu plastične umjetnosti za proletarijat, ${ }^{64}$ a 1940 . izradio je monumentalni predmet kojim je nastojao svijetu predočiti podrijetlo japanske države.

Njegov stav prema društvu bio je dosljedan i jednostavan. Vjerovao je da „zbog proživljenih patnji ne bismo trebali biti ogorčeni na ljude, već iskreni prema sebi, preispitujući vlastite postupke; mislim da je to u svim vremenima predstavljalo nepogrešivi zakon. ${ }^{1{ }^{165}}$

Izgleda kako je Hinago imao razvijenu svijest o orijentalnom duhu. Razdoblje između 1927. i 1929. proveo je u Europi. Kazao je: „Želio sam doći ovamo. Ne provodim vrijeme samo promatrajući i učeći o Europi nego i razmatrajući što bi sami Japanci u njoj mogli uočiti. Dok sam živio u Japanu, nisam bio svjestan ljepote japanskoga izraza, ali sam tek boraveći u Europi to počeo shvaćati. Europa se našla u slijepoj ulici, tražeći orijentalno i u ideologiji i u umjetnosti. (...) Japan sada zauzima najviše mjesto u znanosti i umjetnosti“ . ${ }^{66}$

Snaga Hinagova izraza može se i danas uočiti na simbolu koji je 1931. dizajnirao za Japanski nogometni klub. Ne zna se točno zašto je kao simbol odabran sveti gavran iz jedne stare legende.

http://3.bp.blogspot.com/-05ZlHueU7tl/UaH8bM_8F2I/AAAAAAAAAmU/mXT2w09xeSs/s1600/kanji.jpg

62 "Iz zemlje savršenstva i originalnosti“，Asashi Shinbun, 31. 7. 1998. (唯我独創の国から、朝日新聞、1998 年7月31日付)

63 Ibid. (同上、参照)

64 Usp. „Izložba skulpturâ za proletarijat“, Hochi Shinbun, 15. 5. 1925. (プロのための彫ソ展覧会、報知 新聞、1925年5月15日夕刊)

65 Hinago, „O iskustvu“, Konohana, 41, 1940. (日名子実三、体験を語る、『斯華』、41号、1940年)

66 Isti, „Pismo srednjoj školi 'Usuki'“, Oita Shinbun, 22. 8. 1928. (日名子実三、臼杵中学同空会への手 紙、大分新聞、1928年8月22日付) 


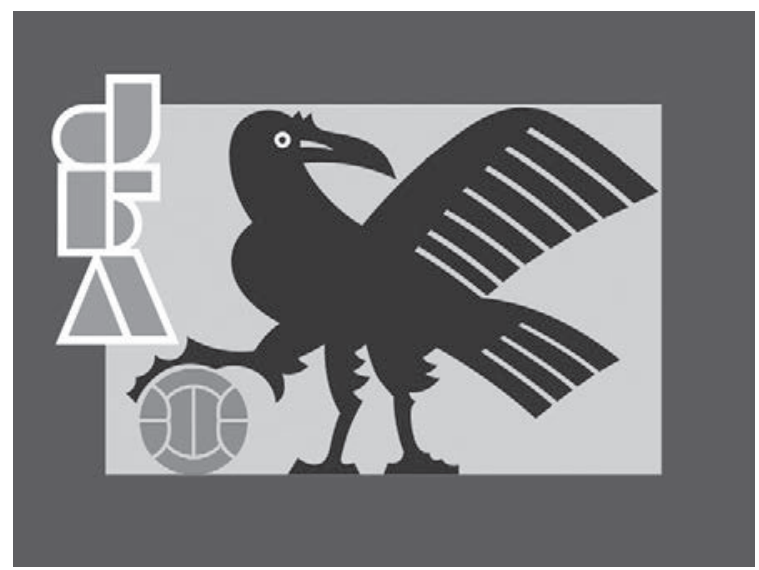

Sl. 11. Jitsuzo Hinago, Simbol japanskog nogometnog kluba (1931. $)^{67}$

Hinago nije objasnio razloge tog odabira. Postoje, naime, tri tumačenja: prvo, da je riječ o znaku poštovanja prema Kakunosukeu Nakamuri, osnivaču prvog nogometnog kluba u Japanu; drugo, zbog svetoga tronogoga gavrana koji se pojavio na velikom hramu u Nachiju, Nakamurinu rodnom gradu (prema tom objašnjenju, kada je car Jinmu napao istočne pokrajine, tronogi gavran pokazivao mu je put); treće, u kineskoj klasičnoj književnosti tronogi je gavran bog sunca.

Godine 1931. japanska Kanto/Kwantung vojska zauzela je cijelu Mandžuriju (sjeveroistočni dio Kine). Šest godina kasnije, u srpnju 1937., dogodio se incident kod mosta Roongdoa i to je bio povod japansko-kineskom ratu. Hinago, kao i Saito, što ćemo vidjeti kasnije, našli su se u teškom položaju.

Tekst koji slijedi jest Hinagov članak objavljen u novinama Yomiuri Shinbun 1940., godinu dana prije izbijanja Pacifičkog rata:

Povijesno gledano, plastična umjetnost, koja je cvjetala u prvoj polovini 8. stoljeća, u eri Tokugawa (1600. - 1867.) gubi na popularnosti, no početkom ere Meiji (1867. 1912.) ponovno oživljava. Razlog je tomu taj što su Japanci, zahvaljujući europskom konceptu i izrazu, uspjeli u dovođenju umjetnosti na prilično visoku razinu. „Međutim, budući da je Francuska bila središnjom zemljom plastične umjetnosti, promjena se dogodila izravnim preuzimanjem francuske umjetnosti, od načina oblikovanja do ideologije. (...) Zbog toga je danas japansko rezbarenje i graviranje u nezavidnom položaju. (...) Poznati umjetnici stvaraju radi vlastite slave, kao što je to i danas tako, no trebali bi stvarati radi vlastitog naroda. (...) Kad govorimo o nacionalnoj umjetnosti, jasno je da se treba udaljiti od prezentiranja golih tijela na izložbama. Osvijestimo djelima značenje japanske umjetnosti i prenesimo to budućim generacijama ${ }^{68}$

67 Izvor: https://matome.naver.jp/odai/2140144631575047101

68 Hinago, „Za skokove naroda!“, Yomiuri Shinbun, 16. 11. 1940. (日名子実三、民族の飛躍に役立て! 、読売新聞、1940年11月16日付) 


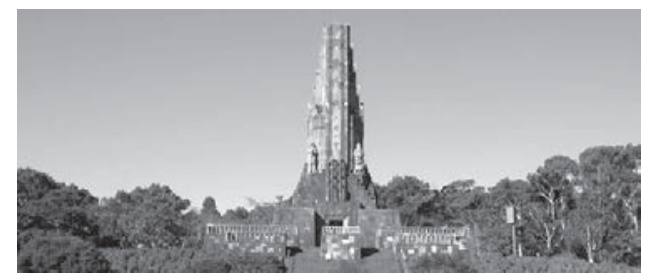

Sl. 12. Jitsuzo Hinago, "Osam uglova svijeta" (1940.) ${ }^{69}$

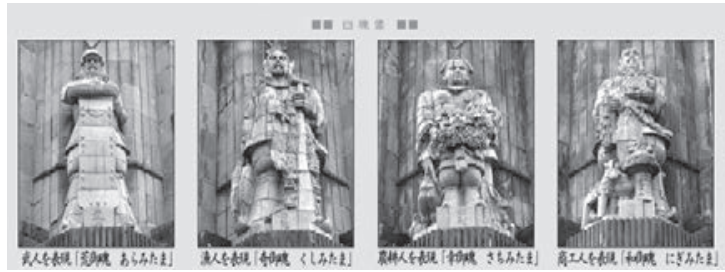

SI. 13. Jitsuzo Hinago, Četiri božanstva na tornju "Osam uglova svijeta"70

Iste je godine Hinago izgradio toranj „Osam uglova svijeta“. Prema njegovoj izjavi ${ }^{71}$, taj je toranj podignut povodom komemorativne svečanosti u prefekturi Miyazaki na 2600. obljetnicu utemeljenja Japana s ciljem da duh hakko-ichiu (što doslovce znači: 'osam uglova svijeta', tj. cijeli svijet pod jednim krovom u smislu univerzalnog bratstva) bude ovjekovječen u velikom zdanju kao mjestu za duhovne vježbe carskoga naroda. Što se oblika tiče, Hinago je naslagao štitove (za obranu cara, kao što se spominje u Nihon-shoki, najstarijoj japanskoj kronici) i imitirao heihaku (papirnate ili svilene trake koje su se kao dar prinosile bogovima). Na prednjoj strani urezana su četiri znaka: hak-ko-ichi-u (osam-uglova-jedan-dom), a oblikovani su i likovi četiriju božanstava (keramički rad): božanstva vojnika, ribara, poljoprivrednika i obrtnika (svaki visine 4,5 metara).

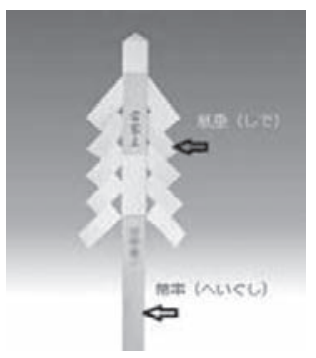

SI. 14. Heihaku

Kasnije se Katsuroku Aikawa, tadašnji guverner prefekture Miyazaki, osvrnuo na izgradnju toga tornja, rekavši: „Ove je riječi prilikom dolaska na prijestolje izgovorio car Jinmu, zadivljen hramom Kashihara u Nari: osam uglova svijeta drži jedan krov, dom, odnosno cijeli svijet. ${ }^{\text {"72 }}$ Guverner je pozvao arhitekte da dostave planove o izradi tornja. Hinago se, prema Aikawi, odazvao pozivu izjavivši: „Bila bi mi iznimna čast kad bih mogao oživotvoriti guvernerovu arhitektonsku ideju, veća nego da postanem član Akademije umjetnosti. Ne trebam nikakvu nagradu, samo mi dopustite da to učinim" ${ }^{73}$

69 Izvor: http://www.miyazaki-city.tourism.or.jp/tourism/spot/20.html

70 Izvor: https://blogs.yahoo.co.jp/pasokondaisukiyo/14907949

71 Usp. Hinago, „O tornju 'Osam uglova svijeta'“, Yomiuri Shinbun, 15. 11. 1940. (日名子実三、八紘之 基柱について、1940年11月15日)

72 Katsuroku Aikawa, „Sjećanje na uspomene“, Tokio 1972, 145. (相川勝六、思い出ずるまま、講談社 出版サービスセンター、1972年、145ページ)

73 Ibid., 138. (同上、138ページ)

Jitsuzo Hinago također je priznao kako je ponudio da to sâm učini. Usp. Hinago, „Toranj ‘Osam uglova svijeta'“, Tokyo Nichinichi Shinbun, 24. 3. 1939. Međutim, Seibo Nishimura, koji je nakon rata napravio spomen-obilježje atomskog bombardiranja Nagasakija, surađivao je u ratu više od Sogana Saita, a Kotaro Takamura, koji je nastavio inzistirati na poštovanju osobnosti umjetnika prije rata, surađivao je u ratu boreći se za narod, iako relativno kratko. 
Danas je potrebno veliku pozornost posvetiti tumačenju i uporabi izraza hak-ko-ichi-u jer se uza nj vežu slike „militarizma“ i "agresije“. Ne bi bilo pošteno kritizirati Hinaga s gledišta današnjih vrijednosti. lako se nije slagao $s$ japanskim stavom o osvajanju svijeta, u ono vrijeme nije mu se mogao usprotiviti. Problem je posebice bio u tome što je „u kamenju za gradnju objekta, nabavljenom iz raznih pokrajina (2.000 komada), bilo i kamenja doniranog iz Kine ${ }^{\text {“74. }}$ U novije je vrijeme otvoreno to pitanje: kustos Narodnog muzeja otpora japanskoj invaziji u Nankingu došao je u Japan sa zahtjevom za odštetu. Može se razumjeti da je među doniranim kamenjem bilo onoga iz Tajvana i Koreje (u ono vrijeme japanske kolonije), pa čak i iz Amerike, s kojom Japan još nije bio u ratu. Međutim, je li uopće moguće da je kamenje bilo donirano iz Kine, s kojom je Japan u to vrijeme ratovao?

Zahtjev za nabavu kamenja iz Kine uputio je zapravo ministar obrane Seishiro Itagaki, koji je guverneru prefekture Miyazaki zapovjedio sljedeće: „svaka bi divizija trebala uzeti dva komada, jedan u blizini područja utaborenja, a drugi iz prvih redova granične crte još nenaseljenog područja. ${ }^{175}$ Ministar obrane je zapovjedniku postrojbe odgovorio da mu pošalje "to kamenje iz prvih redova".

Sâm je Hinago spomenuo uporabu kineskog kamenja pri izradi tornja, no nije o tome ništa pobliže zapisao.

\section{Sogan Saito}

Sogan Saito rodio se 1889. u Tokiju. Godine 1912. završio je Umjetničku školu u Tokiju i postao profesor, a nakon očeve smrti otišao je u Europu i studirao kiparstvo. Nije otišao u Francusku, kamo su u to vrijeme odlazili mnogi kipari iz Japana, nego u "tradicionalniji“ engleski kraj.

\section{Estetika „tradicionalista“ (realizam i romantizam)}

Saito je imao 25 godina kad je u rujnu 1913. krenuo iz Kobea, no nedugo zatim izbio je Prvi svjetski rat. Sve do povratka u Japan 1916., studirao je kiparstvo na Kraljevskoj akademiji u Londonu. Ne zna se točno zašto je odabrao Englesku, ali u jednom od svojih članaka piše: „To nipošto ne znači da sam osobito vezan za prošlost; međutim, u mojim djelima ima elemenata koji se ne smatraju suvremenima." $U$ ono vrijeme većina je umjetnika, napustivši Japan, odlazila u Francusku, no Saito, slijedeći svoju buntovničku narav, uputio se na školovanje u Englesku, zbog čega ga se označavalo tradicionalistom.

U Engleskoj studirao je kiparstvo s Henryjem Alfredom Pegramom (1862. - 1937.). Potonji je bio jedan od vodećih umjetnika nove struje kiparstva tijekom druge polovine 19. stoljeća pa sve do Prvoga svjetskog rata, što je na mladog Saita ostavilo snažan trag. Nova struja kiparstva nije predstavljala nekakav poseban stil, nego oslobađanje od tradicionalnog, a ujedno i potragu za novim stilom i izrazom. ${ }^{76}$ Taj je pristup na tradicionalnu scenu

74 Hinago, „O tornju 'Osam uglova svijeta'“, Yomiuri Shinbun, 15. 11. 1940. (日名子実三、八紘之基柱 について、前掲記事)

75 Svjedočanstvo kamena: nova verzija, Miyazaki 2015, 78. (新版石の証言、みやざき文庫115、鉱脈 社、2015年、78ページ参照)

76 Usp. Horst W. Janson, 19th-Century Sculpture, New York 1985, 240. 
unio dašak svježine. Dominantan stil u kiparstvu bio je realizam, ali je jednako važna bila i uloga skulpture kao arhitektonskog ornamenta, gdje se jednim modelom moglo koristiti za izradu više kopija identičnih oblika, što ju je činilo zanimljivom u komercijalnom smislu. K tomu, još je jedan materijal, aluminij (s drugačijim svojstvima), dodan klasičnima. ${ }^{77}$

Kad se Saito vratio u Japan, na izložbama je vidio isključivo ženske gole figure, čiji su autori pronašli inspiraciju u europskoj tradiciji u prošlosti. Shvatio je da ta prošlost ne implicira samo tradiciju već i narativnost romantizma. ${ }^{78}$ Predložak za skulpturu "Thaïs" (1929.) bio je njegov omiljeni istoimeni roman Anatolea Francea iz doba romantizma.

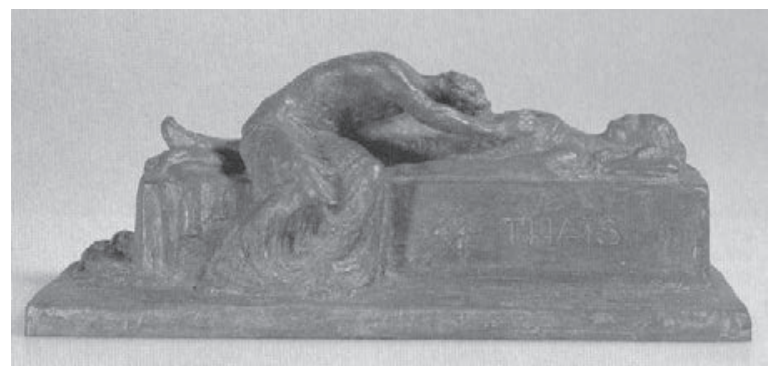

Sl. 15. Sogan Saito, "Thaïs" (1929.) $)^{79}$

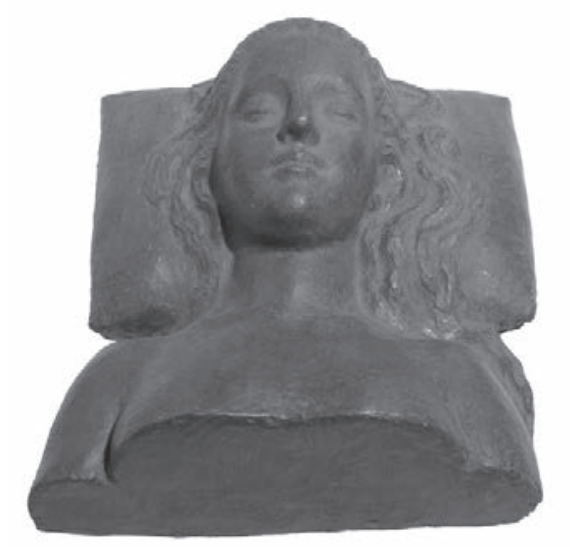

SI. 16. Sogan Saito, "Thaï" (fragment) ${ }^{80}$

Najčešće kritike Saitova djela, u vrijeme dok je bio u "Kozoshi“ pa do 1940., bile su na račun njegova "odnosa prema akademizmu“. Saitove "kamene rezbarije“, koje su trebale biti izložene na „Teitenu“, izložene su, pak, u okviru „Kozoshe“, uz slogan „Dolje akademisti!“ No, Saito se ustvari, barem u ono vrijeme kada je osnovao "Kozoshu“, ni stilom ni ideologijom nije suprotstavljao akademizmu. ${ }^{81} \mathrm{U}$ eseju „Sjećanja na 15 godina“

77 Usp. Kurokawa - Tomomi (ur.), Djelo Sogana Saita, 26. (黒川弘毅・大村友美編、齋藤素嚴の仕事、 前掲書、26ページ参照)

78 Ibid., 29. (同上、29ページ参照)

79 Izvor: Izložba "Kozoshe".

80 Izvor: http://www.city.kodaira.tokyo.jp/bijyutsu/002/images/img_2438_1_1.jpg.html

81 Usp. Izložba „Kozoshe“, 121. (構造社展、前掲書、121ページ参照) 
(1939.) zapisao je: „Budući da nisam odbacio akademizam, nesumnjivo je da je buntovnički duh u mojem načinu života slabo izražen. ${ }^{\text {" } 2}$ Razlog njegova osporavanja "Teitena" bio je njegov djelokrug; smatrao je da je sadržaj postao preopširan. Zbog toga se ne može reći da je Saitov akademizam identičan akademizmu "Teitena“.

Smatra se da je moderno japansko kiparstvo dostiglo "rodinizam“, izraz čovjekove unutrašnjosti, ali ne uključujući pritom „akademski“ način. Tvrdilo se da u Japanu nije bilo "akademizma“. Međutim, razvilo se i drugačije mišljenje kada je Fumio Asakura postao profesor u Umjetničkoj školi u Tokiju, a njegovi bivši studenti ostali su vezani uz "Teiten“, koji doživljava preustroj nakon „Buntena“, od kojega se i razvio.

Stil poput onoga u Umjetničkoj školi ili na izložbama "Teitena“ bio je možda prvi japanski akademski stil. No, Saito, koji je temeljito proučavao kiparstvo zapadne Engleske, odlikuje se zapravo čistim izrazom, iako pomalo ekscentrične tematike. Njegov je rad čak prošao kroz fazu realizma. Ako je tako, "akademizam koji je donio Saito“ mogao bi biti „prvim akademizmom koji se pojavio u Japanu“83.

Nedvojbeno je da je Saitov akademizam igrao važnu ulogu tijekom rata. U tom je razdoblju Saito iskazivao aktivan stav prema ratnoj umjetnosti, ali, kako je napisao u članku iz 1944., objavljenom u novinama Yomiuri Shinbun, „bez obzira na sve druge aspekte ratne umjetnosti, važno je da to bude pravo umjetničko djelo - a to, naravno, zahtijeva vrijeme i svrhu" ${ }^{\text {"84. }}$.

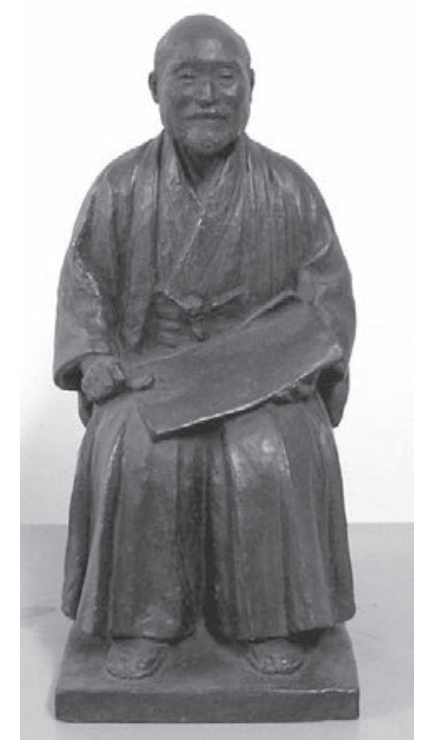

SI. 17. Sogan Saito, "Kip Korekiya Takahashija“ (1940.) ${ }^{85}$

82 Ibid., 266-267. (同上、266-7ページ参照)

83 Ibid., 267. (同上、267ページ参照)

84 S. Saito, „Za Orijent sutrašnjice“, Yomiuri Shinbun, 18. 3. 1936. (斎藤素嚴、明日の東洋のため、読 売新聞、1938年8月18日付)

85 Korekiyo Takahashi (1854. - 1936.) bio je ministar financija šest puta. Kada je pokušao smanjiti vojni proračun, izazvao je ogorčenje vojske. Mladi časnici pobunili su se i ubili ga 1940. Izvor: http://www. city.kodaira.tokyo.jp/bijyutsu/002/images/img_2414_1_1.jpg.html 


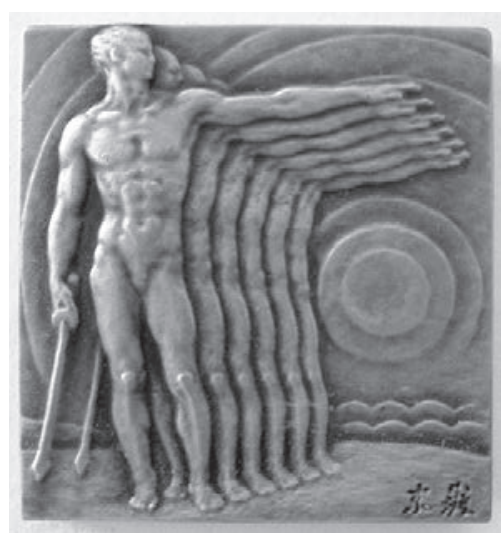

SI. 18. Sogan Saito, Medalja s Istočnoazijskog sportskog festivala povodom komemorativne svečanosti na 2600. obljetnicu utemeljenja Japana (1940. $)^{86}$

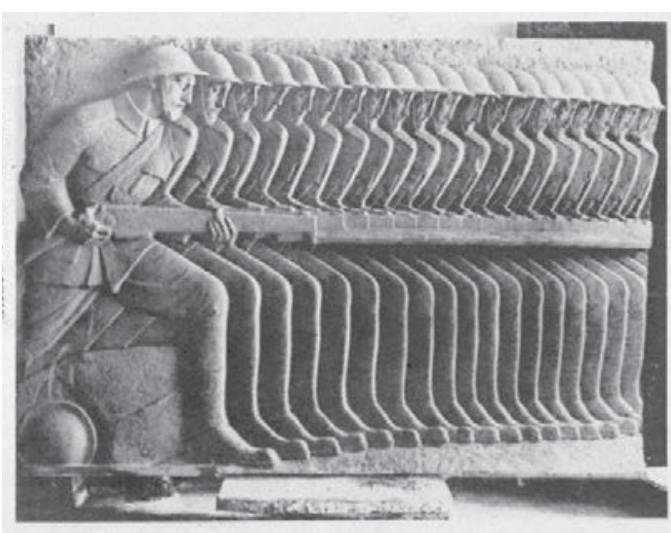

Sl. 19. Ivan Meštrović, "Spomenik ratnim herojima", reljef (1918. $)^{87}$

„Kozosha“ je tijekom ratnih restrikcija 1943. raspuštena, a Saito, osim što je bio ravnatelj na Odjelu za kiparstvo „Nihonbijutsuhoukokukai“ (organizacija za podržavanje militarističkog režima), bavio se i poslovima u vezi s opskrbom kiparskih materijala. Nakon rata izlagao je na 1. „Nitten“ izložbi „Povratak životu (rat, glad, povratak životu)“, a na 2. izložbi predstavio je proturatni kip „Bacamo oružje“. Važno je podsjetiti da „u poslijeratnom razdoblju (i nakon japanskog poraza) nije bilo lako baviti se takvim problemima“88.

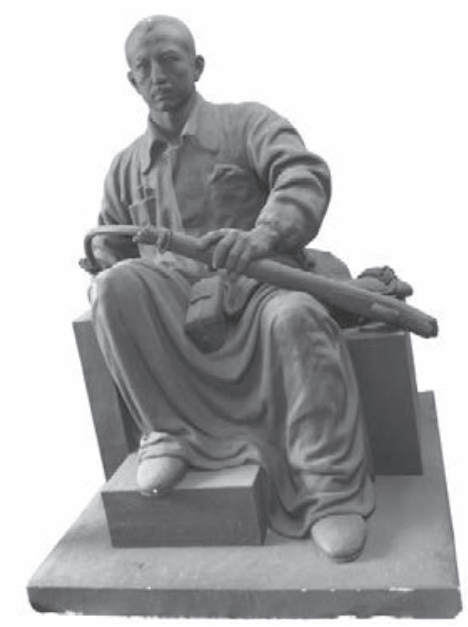

SI. 20. Sogan Saito, "Bacamo oružje" (1946.) $)^{89}$

86 Izvor: http://prewar-sculptors.blogspot.jp/2013/01/blog-post_26.html

${ }^{87}$ Moguće je da je ovaj reljef utjecao na Saitovo djelo „Medalja s Istočnoazijskog sportskog festivala“. Izvor: Meštrovićeva kolekcija kipova, Tokio 1923. (作品集『メストロウィッチの彫刻集』洪洋社,1923年)

88 Kurokawa - Tomomi (ur.), Djelo Sogana Saita, 21. (黒川弘毅・大村友美編、齋藤素嚴の仕事、前掲書、21ペ ージ) 
„Kozosha“ u 21. stoljeću

Godine 2005. održana je prva pokrajinska izložba „Kozoshe“ u Utsunomiyi (kasnije i u nekim drugim pokrajinama), stoga je javnost ponovno skrenula pozornost prema, dotad gotovo zaboravljenoj, ,"Kozoshi“. Slijedi sažetak komentara nakon održane izložbe, kojima je opet istaknuta povijesna uloga Ivana Meštrovića i „Kozoshe“, ukazujući na njihov međusoban odnos:

Usredotočimo se na širenje Art Decoa koji je započeo „Međunarodnom izložbom umjetnosti“, održanom u Parizu 1925., kao i s drugim takvim trendovima u Europi i Americi. U razvoju modernog japanskog kiparstva često se razmatra samo utjecaj francuskog kiparstva, ali ne smijemo zanemariti činjenicu da je hrvatski kipar Ivan Meštrović bio onaj koji je uočio povezanost kiparstva i arhitekture te razvio arhitektonsko-kiparski rad, koji je bio nadaleko poznat i cijenjen.

Čak je grupa kipara nazvana „Todaichosokai“ (na čelu s Asakurom), (...) pokušala urediti izložbeni prostor za biljke, poput vrta, te otad počinje zanimanje kipara za mjesto postavljanja skulpture radi stvaranja odnosa unutar prostora. Ustvari, od 1920ih do 1930-ih arhitekti su dobivali poslove za izradu ornamenata; porasla je čak i potražnja za reljefima. (...) Na 3. izložbi "Kozoshe“ (1929.) impozantan spomenik nazvan "Sintetično djelo“ nastao je suradnjom svih njezinih članova; taj je inovativni rad bio prvi primjer takve vrste. ${ }^{90}$

Kao što smo već vidjeli, čini se da je, osim s Meštrovićem kao pojedincem, postojala i veza između „Kozoshe“ s jedne strane te njemačkog ekspresionizma, Udruge arhitekata secesije i ideološke koncepcije "Memorijalne izložbe mira" s druge. Treba napomenuti da se u vrijeme kada su se japanski arhitekti usredotočili na kulturu koja je bila u stanju mirovanja, sličnu onoj u Koreji i na Balkanskom poluotoku, pojavio kipar Ivan Meštrović. Tada se stav Japana prema Aziji promijenio. Sudeći prema strogim kritikama usmjerenima prema Hinagovu tornju „Osam uglova svijeta”, vidljivo je da je u prvoj polovini 20. stoljeća Japan promijenio stav prema drugim istočnoazijskim kulturama.

Shodno mišljenju kritičarâ, Japan više nije gledao na "Veliku Aziju“, kojom su vladali i s kojom su ratovali 15 godina, kao na monolitni otok. Već sâm izraz "japanska životna crta Seimei-Sen", skovan za sjeveroistočnu Kinu, odnosno Mandžuriju uvijek je slijedio viziju budućnosti u područjima izvan samog Japana. U potpuno koloniziranim zemljama nije bilo ni sjenke te zemlje budućnosti, bila riječ o književnosti, likovnoj umjetnosti ili korejskoj modernoj umjetnosti; bile su iznenađujuće malobrojne umjetničke vrste koje su uključivale opise gradova.

Jedan je povjesničar umjetnosti u časopisu o umjetnosti (1997.) uočio da je Japan vjerojatno bio spreman učiniti Koreju „svojom ruralnom pokrajinom“, a možda je i bio u pravu. Da bi se mogao modernizirati i intenzivno urbanizirati, Japan je morao osigurati zaleđe, za što je najpogodniji bio korejski narod s drevnom kulturnom tradicijom. Japanski jezik, kao i, primjerice, korejska narodna nošnja, mogao bi koegzistirati s japanskom superiornošću i nostalgijom. ${ }^{91}$

89 Izvor: http://www.city.kodaira.tokyo.jp/bijyutsu/002/images/img_2402_1_1.jpg.html

90 Moderno japansko kiparstvo / katalog izložbe, Tokio 2007. (「日本彫刻の近代」カタログ、淡交 社、2007年)

91 Usp. „Velika Istočna Azija“, Muzej japanske umjetnosti, 20. 11. 1997, 1078. (描かれた「大東亜」、日 本美術館、小学館、1997年11月20日、1078ページ参照) 
Već je prije Morinosuke Suwa usporedio Koreju s balkanskim zemljama, hvaleći Meštrovića kao inovativnog kipara/reformista. Njegov mauzolej u Cavtatu smatrao je organski skladnim spojem arhitekture i kiparstva; ta je usporedba, dakle, podrazumijevala da je i Koreja imala mogućnost promjene. Godine 1926. ta se ideja zasigurno razmatrala u svijetu arhitekture.

U Europi razvijalo se novo stanje u umjetnosti, kretanje prema sintezi kiparstva i arhitekture. Taj je razvoj, međutim, pratila svijest o složenim odnosima i razlikama između narodâ i kultura. $U$ tom se smislu može reći da je pravi predstavnik tog pokreta bio Meštrović, hrvatski Rodin. Kanji Yo mnogo je naučio od Meštrovića pa je u svojim radovima, kao stručnjak za proučavanje kineske kulture, dodao orijentalne elemente. Saito je, zahvaljujući svojem akademizmu, nastavio stvarati i tijekom rata, ali je tek poslije katkad postajao svjestan aktivnosti u tom ratnom razdoblju. Hinago, vođen željom za stvaranjem, izradio je kulturni spomenik u čast svojoj zemlji, no budući da se nije protivio prikupljanju kamenja iz zaraćene Kine, stječe se dojam da je njegov modernizam bio pod utjecajem nacionalizma.

Razmatrajući ulogu arhitekta/kipara u vrijeme raspada „Kozoshe“, postaje jasno da je razmjena mišljenja i kulture, koja je nekad prelazila granicu, smanjena, dok je istodobno odnos japanskog društva prema umjetnosti postao homogen. Potonje su dvije sastavnice, prema mojemu mišljenju, neraskidivo povezane. Da bi se spoznala obilježja čitave grupe okupljene oko "Kozoshe“, potrebno je usmjeriti se ne samo na proučavanje problema stavova prema etničkim grupama nego i prema samom ratu.

\section{Poslije „Kozoshe“}

Deset godina nakon održavanja pokrajinske izložbe „Kozoshe“ izdana je knjiga Rat i umjetnost (u suautorstvu s Akihisom Kawadom), iz koje je razvidno da je važno razumjeti kontekst "sintetičnog djela“ "Kozoshe“:

U kakvoj bi vezi trebala biti skulptura s gradskom okolinom, kako je ondje smjestiti, pronaći izraz koji nadilazi pojedinačno postajući grupnim; s druge strane, pozornost treba skrenuti na činjenicu da takvo radikalno istraživanje zapravo označava podržavanje militarističkog režima, o čemu svjedoči djelo "Osam uglova svijeta“, nastalo kasnije u ratnom razdoblju. ${ }^{92}$

Međutim, ako je ta kritika točna, ona se odnosi samo na Hinaga, a ne i na cijelo Društvo „Kozosha“. Kanji Yo i Ogishima (te još neki drugi) u ratnom su periodu već bili mrtvi, a promatrajući Saitova djela koja prikazuju Takahashija, ne može se nužno tvrditi da je umjetnik podupirao militaristički režim.

Prema Akihisi Kawadi, Taikan Yokoyama (orijentalno slikarstvo) i Tsuguharu Fujita (zapadnjačko slikarstvo), značajni predstavnici svojih stilova, surađivali su tijekom rata, a novine Asahi i Yomiuri Shinbun objavljivale su ratne slike. $U$ tome smislu suradnja u ratu nije bila samo problem umjetnika kao pojedinca već i umjetničkog svijeta u cjelini.

92 Akihisa Kawada (ur.), Japanska umjetnička zbirka, knj. 18: Prije rata/Tijekom rata. ",Rat i umjetnost", Tokio 2015, 186. (河田明久編、日本美術全集第18巻戦前・戦中 戦争と 美術、小学館、2015年、186 ページ) 
Razmatrajući odnos umjetnosti i društva za vrijeme Prvoga i Drugoga svjetskog rata, moći ćemo spoznati da se on uvelike promijenio. $U$ tom su pogledu značajni argumenti koje je iznio povjesničar umjetnosti Akihisa Kawada.

Počevši od sredine 3., kao i u cijelom 4. desetljeću prošlog stoljeća, zbivale su se velike političke i društvene promjene. Gradovi su bili blistavi i živopisni, no ispod te površine krila se loša gospodarska situacija koja je dovela do štrajkova. Glavno "lice“ tog vremena definitivno više nije bila elitna šačica ljudi, već bezlična, nadmoćna masa. Teoretičari umjetnosti bili su svjesni da je time umjetnost ostavljena negdje u pozadini. Promjene u umjetničkom svijetu započele su u ljevičarskom bloku, a zatim je uslijedio pokret narodne umjetnosti i potraga za ljepotom u proizvodima bezimenih obrtnika. $\mathrm{U}$ tako nemirnom i promjenjivom razdoblju utemeljeno je Društvo kipara „Kozosha“. Osim potonjeg, bilo je i umjetnika koji nisu izlagali na izložbama, nego su se bavili oslikavanjem zidova. Jedan od njih bio je i Tsuguharu Fujita. Ipak, sve dok je prevladavala svijest da se radi o tokonomi (zidna niša za smještaj cvijeća), japansko slikarstvo nije moglo prijeći granice tradicionalnog izraza. "Svi bi se trebali pojaviti na izložbi i surađivati kako bi čitavo mjesto pretvorili u veliko slikarsko platno; nije li to ono što suvremeni stil od nas zahtijeva?", ${ }^{93}$ izjavio je Ryushi Kawabata, koji se zalagao za nadilaženje tih granica. Kasnije je postao jedan od ratnih umjetnika.

\section{Izgredi na državnim izložbama}

Vjerojatno je glavna promjena, koja je započela 1935. reorganizacijom "Teitena“ (izložba koju je organizirala Carska akademija), uvukla u vrtlog zbivanja i čitav umjetnički svijet. U suradnji s glavnim nevladinim organizacijama, kao što su Nikakai i Nihonbijutsuin, ministar obrazovanja Genji Matsuda ocijenio je rad „Teitena“ neučinkovitim s obzirom na to da je na tim izložbama bio i velik broj djela i izlagača koji nisu podvrgnuti ispitivanju jer su imali povlasticu kao veterani Carske akademije. Zbog toga je naziv „Teiten“ promijenjen u „Bunten“ (izložbu je organiziralo Ministarstvo obrazovanja). Međutim, rezultat je bio upravo suprotan. Promjena koju je prouzročila ova reforma izazvala je raskol između „Buntena“ i nevladinih organizacija umjetnikâ jer su malobrojna bila djela onih umjetnika koji nisu mogli sudjelovati u kvalifikacijama zbog nepodlijeganja ispitivanju. Matsudina reforma trebala je biti usmjerena protiv društvenog vodstva, no umjesto toga pogodila je umjetnike. S gledišta umjetnikâ koji su bez ispitivanja izlagali na izložbi „Teiten“, a koje se potom označavalo "netalentiranima“, postavljalo se pitanje što je to uopće talent i mogu li ga ljudi tako lako prepoznati. Nije slučajnost da su slikari, koji su kasnije djelovali kao ratni umjetnici, u to vrijeme bili dijelom skupine autorâ koji su izlagali bez podvrgavanja službenoj ocjeni. ${ }^{94}$

\section{Naracija i bojište}

Čak je i prije te reforme otvorena zanimljiva rasprava o pitanju talenta i načinu njegova prepoznavanja. Neki su mislili da su dotadašnje izložbe bile dosadne jer nije bilo slika

93 Ibid., 175. (同上、175ページ)

94 Ibid. (同上、参照) 
koje bi izazvale reakcije promatračâ; nedostajali su elementi priče. Za umjetnike bilo je potrebno prilagoditi se uvjetima i surađivati s drugima kako bi se proizvela umjetnost koja će privući promatrače. S modernističkog stajališta, takvo stanje u umjetnosti može izgledati retrogradnim, ali slikari 1930-ih željeli su stvoriti djelo ne oslanjajući se na pojedinca a da pritom bude zanimljivo svima. Taj nas stav podsjeća na onaj kasnijih ratnih slikara. Moglo bi se reći da je ratni slikar rođen prije samog rata. ${ }^{95}$

\section{Slikari i bojište}

Povijesno gledano, razdoblje od incidenta u Mandžuriji 1931. do kraja Drugoga svjetskog rata 1945. može se podijeliti na tri dijela: prvi obuhvaća period od mandžurijskog incidenta do 1937., odnosno godine sukoba japanske i kineske vojske, drugi obuhvaća japansko-kineski rat od 1937. do kraja 1941., a treći razdoblje od rata na Pacifiku do kraja Drugoga svjetskog rata, koji je završio porazom. Međutim, prvi period, barem za japanske umjetnike, nije bio ratni. Bilo je umjetnika koji su odlazili na bojište u znak prosvjeda protiv incidenta u Mandžuriji, kao i u Šangaju, no bila je riječ samo o manjini. Bojno polje japanskih umjetnika nalazilo se zapravo u zemlji. Postavljalo se pitanje: kako bi oni mogli zaustaviti propadanje umjetnosti i vratiti posjetitelje na izložbe? Kako bi mogli pronaći šarm i izraz u umjetnosti, u kojoj su dominirali film i kazalište te komercijalne i ilustrativne umjetnosti a da ne zaostaju za njima? Moglo bi se reći da je izbijanje japansko-kineskog rata u srpnju 1937. u ironičnom obliku otvorilo proboj i donijelo odgovor na ta pitanja. Broj umjetnikâ koji su išli u rat danomice se povećavao. Do 1939., poslije dviju ratnih godina, na bojištu je bilo više od 200 umjetnika. ${ }^{96}$

\section{Dva poslijeratna pristupa}

Nakon konačnog poraza u jednom se trenutku ozbiljno raspravljalo o tome kako shvatiti novu stvarnost s obzirom na temeljni pad vrijednosti u tadašnjem društvu. Poslijeratni umjetnici imali su odgovor na to pitanje. Niz produkcija nazvanih "reportažno slikarstvo“, pokazujući zanimanje za radnički i narodni pokret, a ujedno i kritizirajući režim 1950-ih, bio je u političkom smislu u sukobu s idejama koje su podržavale najnoviju ratnu umjetnost. Međutim, umjetnici su smatrali da bi proširenjem primijenjene umjetnosti ona mogla biti sredstvom prenošenja poruka (bilo predratne proleterske, bilo ratne umjetnosti).

S druge strane, većina je umjetnika u svojim djelima odlučila izbaciti „poruke“. Od razdoblja okupacije pa sve do 1950-ih važnost poprimaju radovi s fragmentima ili motivima koji su gledatelje podsjećali na izblijedjelo ljudsko tijelo. Ta su djela odbacila intelektualno u korist vizualnog, pokazujući posjetiteljima čitavu besmislenost ljudskog postojanja, predstavljajući pritom snažnu reakciju na ratnu umjetnost, koja je pridavala pretjerano značenje ljudskom tijelu kao subjektu u svojim djelima.

Slično mišljenje o značenju u umjetnosti prevladavalo je, prema Kawadinu mišljenju, i među suvremenim umjetnicima, koji su pokušali odbaciti materijal kao sredstvo izražavanja, ali i sadržaj te njegovu primjenu. Pedesetih godina 20. stoljeća slikari su prikazivali

95 Ibid. (同上、参照)

96 Ibid., 176. (同上、176ページ参照) 
osobna ratna iskustva, što dokazuje da ta dva pravca nisu neminovno bila u opreci. Gola tijela koja se prikazivalo bila su besmislena, no, prema Kawadi, istodobno su služila i kao izvor snažnih poruka. ${ }^{97}$

Može se, dakle, vidjeti kako se u Japanu bavilo pitanjima umjetnosti - o njezinoj svrsi, odnosu prema društvu, značenju priče, položaja ljudskog tijela itd. Upravo je ta pitanja Društvo „Kozosha“ postavilo i pokušalo riješiti pa se u tom smislu ljude nastojalo primorati na razmišljanje. Hinagov toranj „Osam uglova svijeta“ bio je eksperimentalan pokušaj sinteze kiparstva i arhitekture početkom 1940-ih. Budući da se narativni izraz tog djela više temelji na legendi nego na povijesti, može biti prilično otežano razumijevanje drugih naroda. Naposljetku, taj impozantni spomenik služi poput ozbiljnog upozorenja da bismo važna pitanja koja postavlja umjetnost trebali rješavati na razini realističke društvene/nacionalne svijesti. Saito je, samo njemu svojstvenim akademizmom i priznavajući društvo na donekle realističan način, pokušao održati samu bit umjetnosti, čak i tijekom rata. U povijesti japanske umjetnosti i Japana općenito njegov životni vijek i djelo trebali bi se više vrednovati.

U međuvremenu, bježeći od okupacijskog režima u Dalmaciji i izbjegavajući da ga fašistička Italija iskoristi u političke svrhe, Meštrović je tijekom Drugoga svjetskog rata otišao u SAD. lako je ondje ostao i poslije rata, održavao je dobar odnos s Titovom Jugoslavijom. Njegova stvaralačka snaga te razumijevanje hrvatske seoske kulture i danas zauzimaju visoko mjesto u povijesti umjetnosti i povijesti hrvatskog društva.

(Prijevod Mirna Potkovac-Endrighetti)

97 Ibid., 183. (同上、183ページ参照) 